\title{
Traditional and Phytochemical Bases of Herbs, Shrubs, Climbers, and Trees from Ethiopia for Their Anticancer Response
}

\author{
Limenew Abate $\mathbb{D}^{\mathbb{D}}{ }^{1,2}$ Mesfin Getachew Tadesse $\mathbb{D}^{1},{ }^{1}$ Archana Bachheti $(\mathbb{D})^{3}$ \\ and Rakesh Kumar Bachheti $\mathbb{D}^{1,2}$ \\ ${ }^{1}$ Department of Industrial Chemistry, College of Applied Science, Addis Ababa, P.O. Box-16417, Ethiopia \\ ${ }^{2}$ Centre of Excellence in Nanotechnology, Addis Ababa Science and Technology University, Addis Ababa, P.O. Box-16417, Ethiopia \\ ${ }^{3}$ Department of Environmental Science, Graphic Era University, Dehradun, Uttarakhand, India
}

Correspondence should be addressed to Rakesh Kumar Bachheti; rkbachheti@gmail.com

Received 11 August 2021; Revised 25 November 2021; Accepted 31 December 2021; Published 3 February 2022

Academic Editor: Chen-Huan Yu

Copyright (c) 2022 Limenew Abate et al. This is an open access article distributed under the Creative Commons Attribution License, which permits unrestricted use, distribution, and reproduction in any medium, provided the original work is properly cited.

\begin{abstract}
Ethiopia is one of Africa's six plant-rich countries, with around $60 \%$ of the plants being indigenous and most of them having medicinal properties. $80 \%$ of people in the country use these plants as a primary health care system to tackle different diseases, including cancer. This review is aimed at summarizing the evidence gained from diverse MPs in Ethiopia that have been used ethnobotanically and ethnopharmacologically for treatment of cancer. The primary data sources were Google Scholar, Web of Science, Science Direct, Scopus, PubMed, and other electronic scientific databases. This literature review showed that there are around $200 \mathrm{MPs}$ used as anticancer. Seventy-four herbs, 39 trees, 77 shrubs, and 17 weed/climbers belonging to 56 families have been identified for their ethnobotanical anticancer potential, and 31 species were recognized for their pharmaceutically anticancer activities. The reviewed data also indicated that many Ethiopian MPs had been used to treat breast, lung, blood, and skin cancers and other tumors. Besides, the collected data showed that the leaves (36.76\%), roots (27.2\%), bark (12.5\%), stem (5.1\%), and fruit $(7.35 \%)$ of plants are commonly used for the preparation of anticancer remedies. Among the reported plant species, Euphorbiaceae (10.71\%), Acanthaceae (7.14\%), and Asteraceae (7.1\%) are the most prominent plant families being used to treat cancer ethnobotanically. Phytochemicals such as flavonoids (like xanthone, indirubin, flavopiridol, and silybin), alkaloids (like taxol, vincristine, evodiamine, and berberine), and physalin B, D, and F steroids exhibited anticancer activity on various cancer cell lines. The crude extracts of Aerva javanica, Vernonia leopoldi, Withania somnifera, Kniphofia foliosa, and Catharanthus roseus were powerful anticancer agents with an $\mathrm{IC}_{50}$ value below $10 \mu \mathrm{g} / \mathrm{mL}$. Although several Ethiopian plants possess anticancer potential, only a limited number of plants are scientifically studied. Therefore, more scientific studies on anticancer MPs should be carried out; it may lead to discovering and isolating cost-effective and safe anticancer drugs.
\end{abstract}

\section{Background}

Plants are the sources of different chemical constituents such as essential oils, seed oils, and other phytochemicals, which gives a potential for various applications and pharmaceutical uses [1-4]. Specifically, traditional MPs (TMs) keep us healthy and treat different illnesses [5]. People have used TMs as primary health care contributors for thousands of years, and they play a vital role in preventing many diseases in resource-limited areas of developing countries $[6,7]$. Nowadays, more attention has been given to TMs by differ- ent researchers because they can generate many uses and applications in the line of medicine and pharmacy [8]. In China, from total medicinal consumption, about $30 \%$ to $50 \%$ was gained from medicinal plants (MPs) [9]. In India, there are 17,500 native plant species from these 7,500 species that are used in ethnomedicines. About 2,000 aromatic and medicinal plant species are commercially used in Europe, while over 5,000 plant species are estimated to be used for medicinal purposes in Africa [10]. In Mali, Ghana, Nigeria, and Zambia, $60 \%$ of children's first treatment is obtained from a medicinal plant. In Ethiopia, approximately $80 \%$ of 
the population uses MPs because of the cultural suitability for local medicine [9].

Ethiopia has a vast diversity of plant species due to the presence of various topographical settings, ranging from the highest mountain to a deep valley; as a result, Ethiopia is rich in MPs [11]. There are about 6,000 plant species in the country, with 12 percent of them being endemic [12]. In Ethiopia, more than 800 plant species have been claimed to treat more than 300 ailments [13]. The bioactive compounds are responsible for the pharmaceutical properties of MPs [14] and can be isolated from plant seeds, fruits, bark, leaves, stems, roots, and flowers [15]. Alkaloids, terpenoids, flavonoids, glycosides, and polyphenols are bioactive compounds obtained from MPs and are used to cure various diseases, including cancer [16].

Nowadays, cancer is one of the deadliest diseases in the world, which has been estimated to cause 9.9 million deaths in 2020 [17]. It also becomes a health problem in Ethiopia [18]. According to the report of Woldu et al. [19], each year, there are more than 150,000 cancer cases reported in the country; from these, about $4 \%$ result to deaths. The data obtained from the WHO indicated many types of cancers in Ethiopia; some of them are blood cancer, lung cancer, skin cancer, breast cancer, etc. [20]. Local people of Ethiopia have used different traditional practices to treat cancer [21]. MPs have been highly demanded in Ethiopia to treat cancer disease, because of their relatively low cost, the trust of communities on medicinal values of TMs being high, inadequate health centers, and shortage of drugs and personnel in clinics [13]. Some of the frequently cited anticancer MPs used by Ethiopian people to treat different types of cancers are Aerva javanica, Bersama abyssinica, Asparagus africanus, Brucea antidysenterica [22], Nigella sativa [23], Matricaria chamomilla, Foeniculum vulgare [24], Zingiber officinale, Hibiscus sabdariffa, Glinus lotoides, Mentha piperita, Trachyspermum Ammi [25], Lepidium sativum [26], Commiphora myrrha [27], Ruta chalepensis [28], and Lippia adoensis [29] as illustrated in Figure 1.

Although several Ethiopian plants were known to possess anticancer activity, very little scientific research is carried out on these MPs [30]. Also, a limited number of classes of secondary metabolites and pure isolated compounds were tested against cancer cell lines. Insufficient documentation on the ethnobotanical use of anticancer MPs is another problem in sharing traditional medicinal knowledge [31]. This review is aimed at giving an overview of the ethnomedicinal and phytochemical bases of anticancer MPs of Ethiopia.

\section{Methods}

Published research papers, review papers, proceedings, short communications, and book chapters on different MPs used to treat various forms of cancer in Ethiopia were retrieved from multiple databases such as PubMed, Web of Science, Scopus, and Google Scholar. More than 100 publications were obtained from 2007 to 2020. In the search process, keywords phytochemistry of anticancer plants of Ethiopia, traditional anticancer medicinal plant of Ethiopia, MPs used against cancer/tumor in Ethiopia, herbal medicine traditional medicine used against cancer in Ethiopia, and bioactive compounds isolated from the anticancer medicinal plant of Ethiopia were used. We classified the data according to the type of cancer (breast cancer, lung cancer, blood cancer, and skin cancer) and medicinal plant habits (shrub, herb, tree, weed, and climber). Additional important papers were also examined based on the reference list of the retrieved documents. ChemDraw was used to draw the structure of bioactive compounds, and pie charts were prepared using Excel software, while Endnote performed reference writing. We use the Natural Products Database for Africa (NDA) to write the botanical name and the local name of the medicinal plant.

\section{Cancer Status in Ethiopia}

Ethiopia is Africa's second-most populous country, and it is forecasted to become the world's ninth most populous country by 2050, with a projected increase in cancer burden [32]. Cancer is expected to account for around $5.8 \%$ of total national mortality in Ethiopia. Except for Addis Ababa, where population-based statistics are available, it is estimated that the annual incidence of cancer is about 60,960 cases and the annual mortality is over 44,000 [33]. According to a World Health Organization report on cancer [34], 77,352 new cancer cases were reported in both sexes of all ages, of which 26,754 were male of all ages and 50,598 were female of all ages. This showed that the number of new female cancer cases is $89.8 \%$ higher than that of males. Some of the recorded new cancer cases in 2020 were breast cancer (20.9\%), leukemia (5.6\%), cervix uteri (9.6\%), colorectum (3.6\%), and non-Hodgkin lymphoma (4.9\%) (Table 1), and the mortality rates in the specified year were $24.1 \%$ (breast), $16.0 \%$ (cervix uteri), 3.9\% (leukemia), 5.5\% (ovary), 3.6\% (lung), 3.4\% (stomach), 5.5\% (colorectum), and 5.9\% (prostate) [34]. According to Tuasha et al. [11], from the total medicinal plant consumption used to treat cancer, $44.33 \%$ accounts for neck cancer, $14.0 \%$ breast cancer, and $10.67 \%$ skin cancer. The rest are the cancer of the brain, bone, rectal, lung, anus, cervix, and others.

3.1. Ethnobotanical Survey of MPs for Cancer Treatment. MPs are essential part of human life. For more than 2,000 years, they have been used as alternative medicine in the world [11]. Approximately $80 \%$ of these MPs globally are essential as the primary healthcare for fighting infections and treating illness [35]. MPs have been in continuous use over the years to manage cancer, particularly in most developing countries of the world [36]. The bioactive compounds of phytochemicals present in MPs are used to treat different diseases, including cancer [37]. For example, around $60 \%$ of drugs necessary for the cancer cure system have been derived from natural products of MPs [38]. Aromatic MPs are also crucial for medicinal purposes; they were considered the "father of medicine" by Hippocrates and ancient Greek physicians. Treating cancer and AIDS/HIV are their main benefits [21]. 


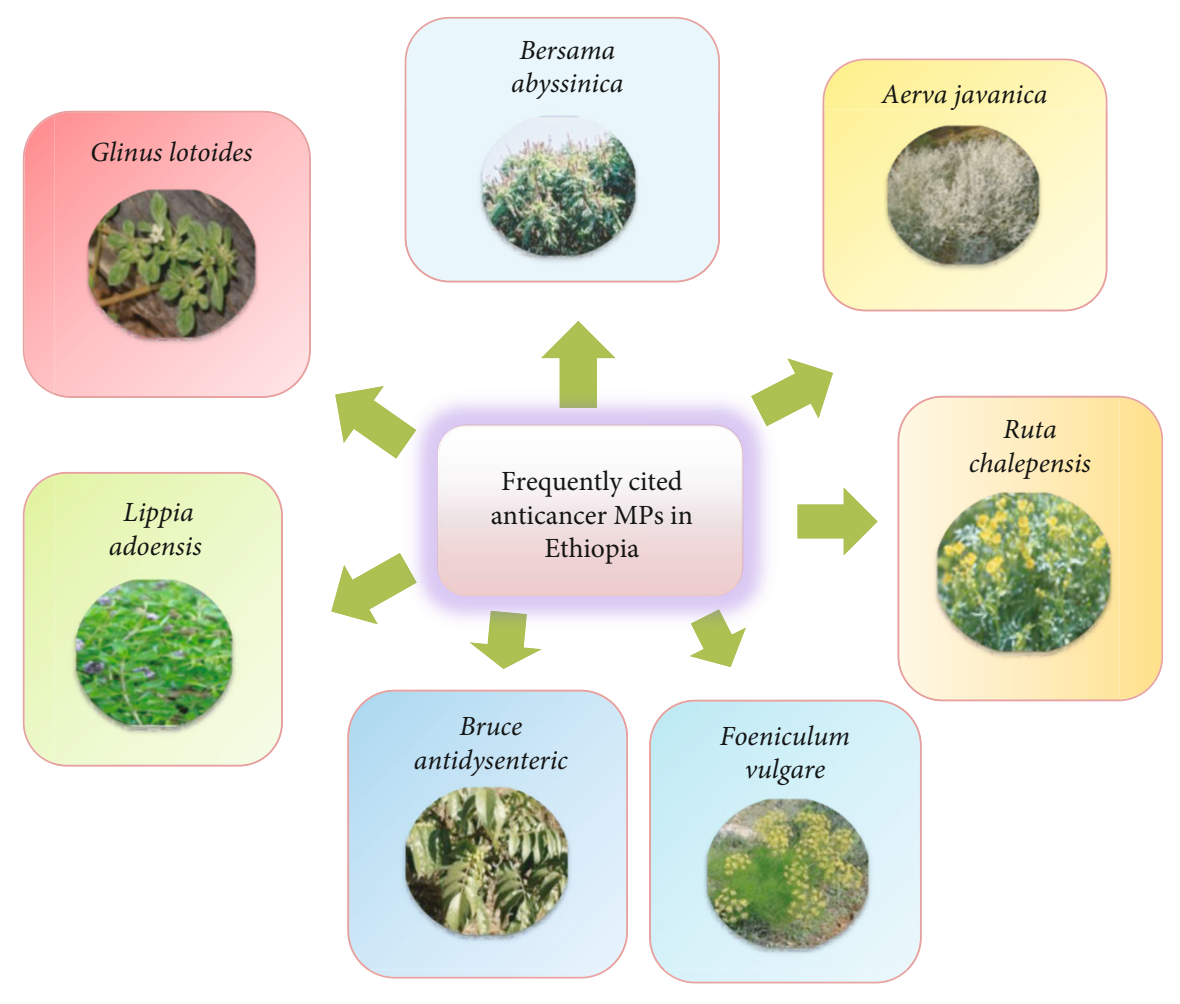

Figure 1: Frequently cited anticancer MPs found in Ethiopia.

TABLE 1: Number of new cancer cases in 2020 in Ethiopia in number and percentage [34].

\begin{tabular}{lccc}
\hline New cancer cases & Both sexes of all ages & Males of all ages & Females of all ages \\
\hline Non-Hodgkin lymphoma & $3,824(4.9 \%)$ & $2,359\left(8.8 \%^{\prime}\right)$ & $1,465(2.9 \%)$ \\
Leukemia & $4,361(5.6 \%)$ & $2,565(9.6 \%)$ & $1,796(3.55 \%)$ \\
Cervix uteri & $7,455(9.6 \%)$ & - & $7,455(14.7 \%)$ \\
Breast & $16,133(20.85 \%)$ & - & $16,133(31.9 \%)$ \\
Colorectum & $6,048(7.8 \%)$ & $3,121(11.7 \%)$ & $2,927(5.8 \%)$ \\
Prostate & $2,720(3.51 \%)$ & $2,720(10.2 \%)$ & - \\
Ovary & $2,655(3.43 \%)$ & - & $2,655(5.2 \%)$ \\
Other cancers & $34,156(44.15 \%)$ & $15,989(59.76 \%)$ & $18,167(35.9 \%)$ \\
Total & 77,352 & 26,754 & 50,598 \\
\hline
\end{tabular}

Many medicinal plant species found in Ethiopia are used to treat different types of illnesses for many years. Because the society believes in the therapeutic value of traditional medicines, of health center insufficiency, of the relatively low costs, of culturally related traditions, and of shortages of clinics and medical personnel, they are very popular in Ethiopia [13]. In Ethiopia, a large number of the human population (80\%) and livestock (90\%) directly or indirectly depend on traditional medicine [39]. According to a study conducted on traditional MPs in Ethiopia, the frequently cited diseases treated by these plants were cancers/tumors, stomach aches, wounds, coughs, headaches, skin diseases, toothaches, and diarrhoea [13]. Different studies on the ethnobotanical use of MPs from other parts of the country showed that traditional MPs are widely practiced to treat various cancer diseases such as lung cancer, breast cancer, and skin cancer [11]. Because of its ease of access and cultural acceptance, cancer patients choose traditional MPs for therapeutic approaches [40]. Ethnobotanical practices to treat cancer in Ethiopia are listed in Table 2.

Table 2 shows the list of 200 MPs which are used ethnobotanically against anticancer. Out of these, 33.8\% are herbs, $17.9 \%$ trees, $39.5 \%$ shrubs, and $8.8 \%$ weed/climbers. Among the 56 families, Euphorbiaceae (10.71\%), Acanthaceae (7.14\%), and Asteraceae (7.1\%) are the most prominent families which are used for ethnobotanical anticancer preparation. Regarding their distribution, 24\% of MPs were found in Southern Nations, Nationalities, and People (SNNP), $21 \%$ in the Oromia region, and $20 \%$ in the Amhara regional state, as shown in Figure 2. The reviewed data also indicated that many Ethiopian MPs had been used to treat breast, lung, blood, and skin cancers. Plant sections that are widely 


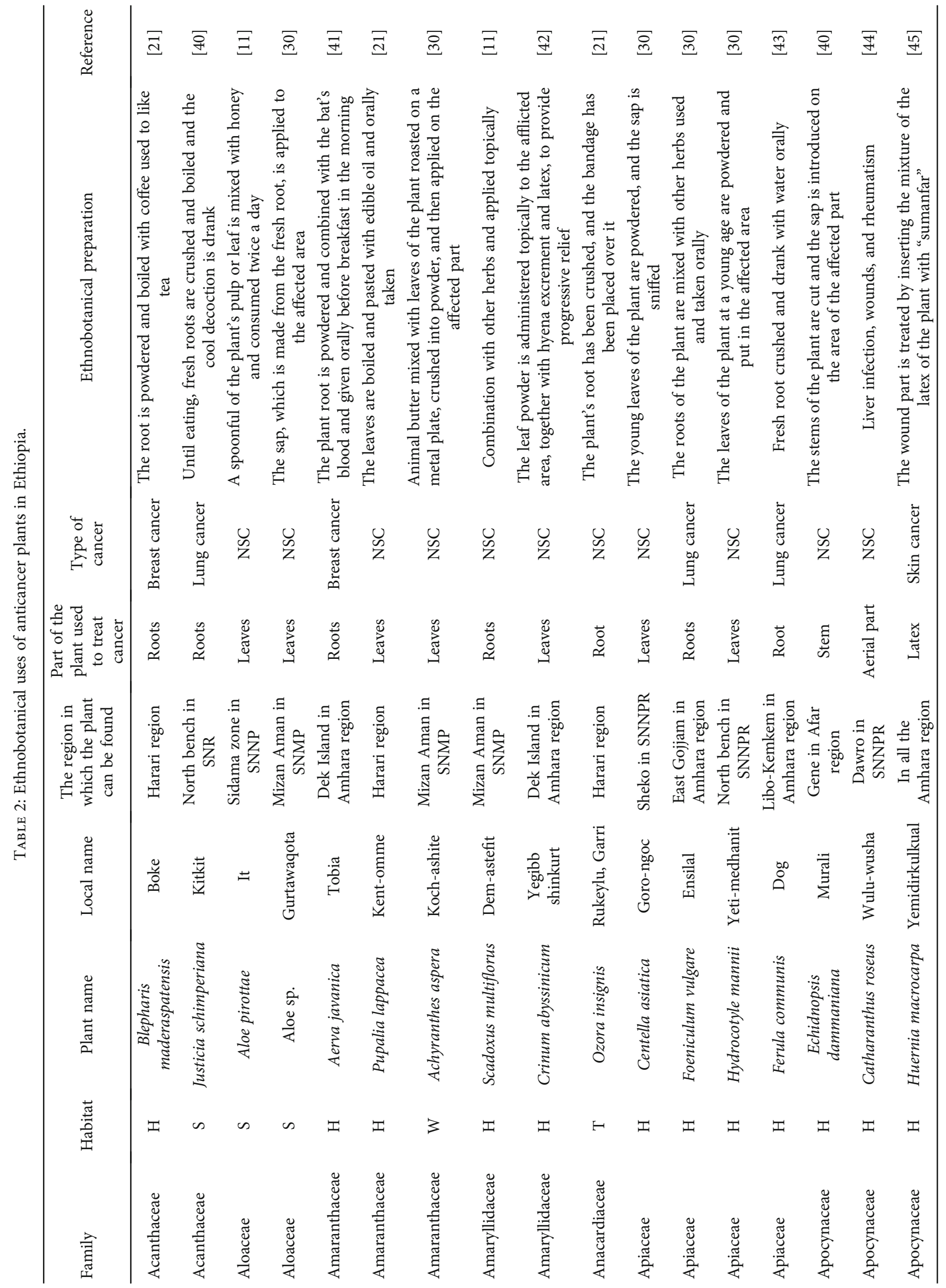




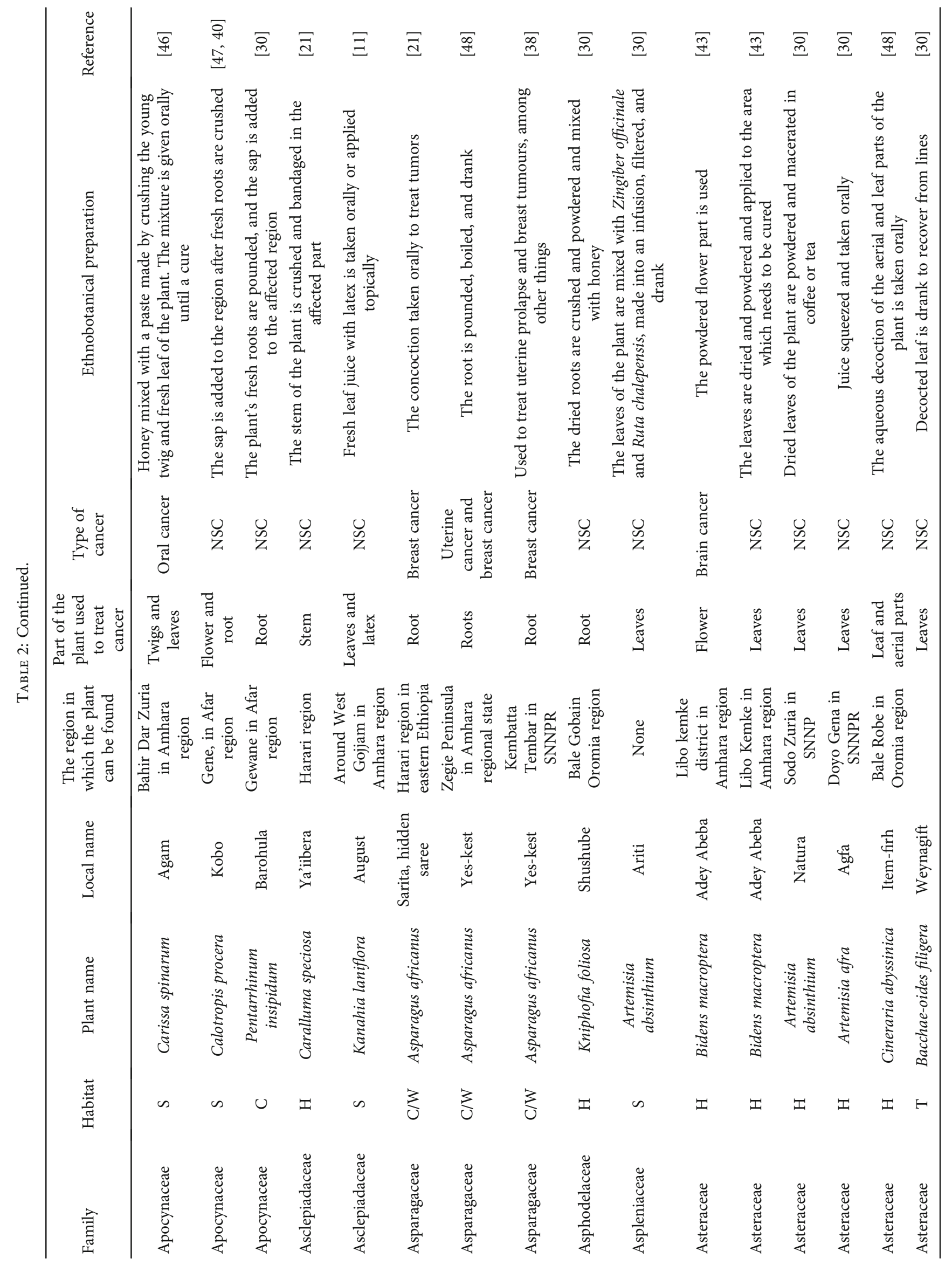




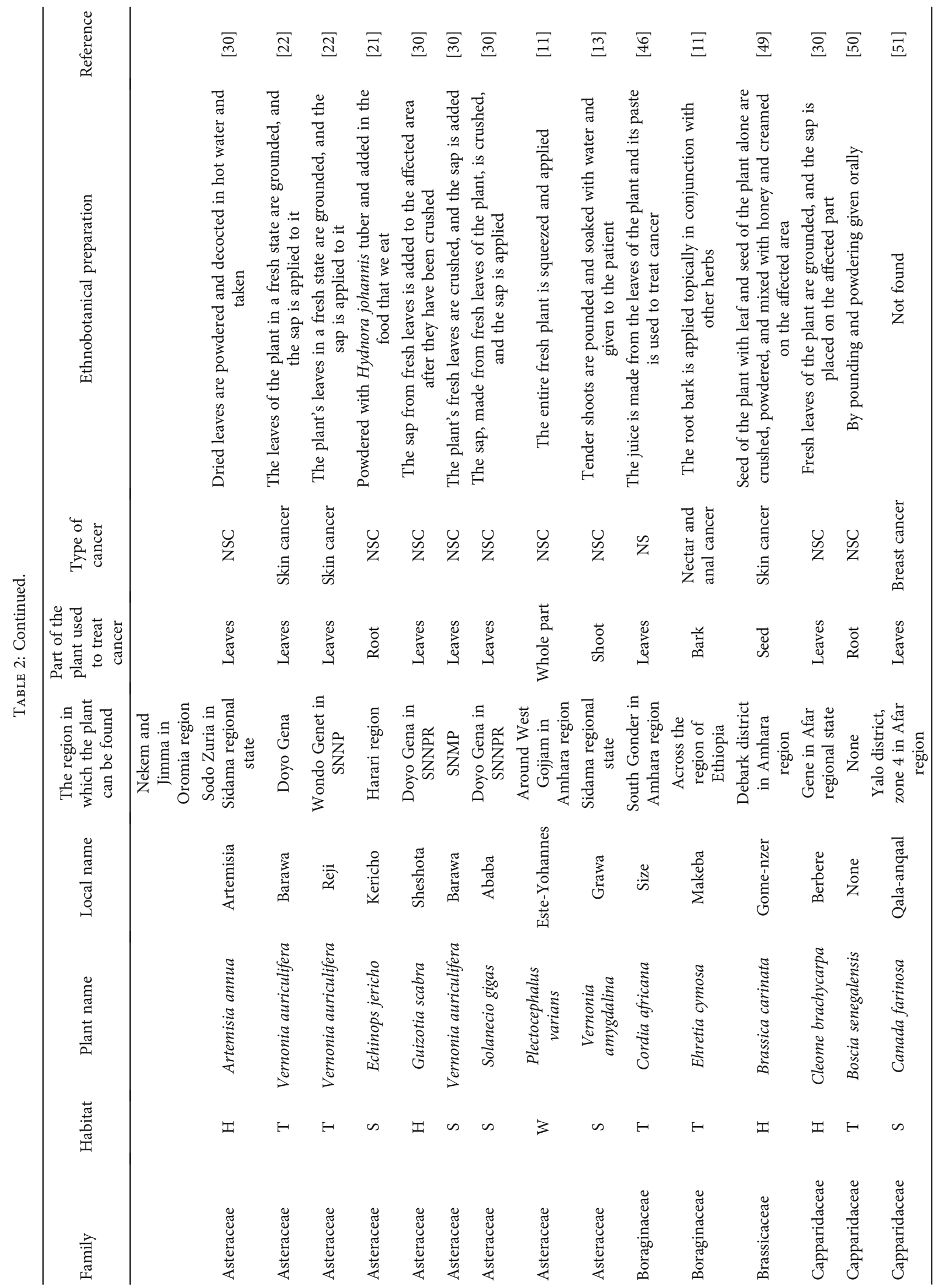




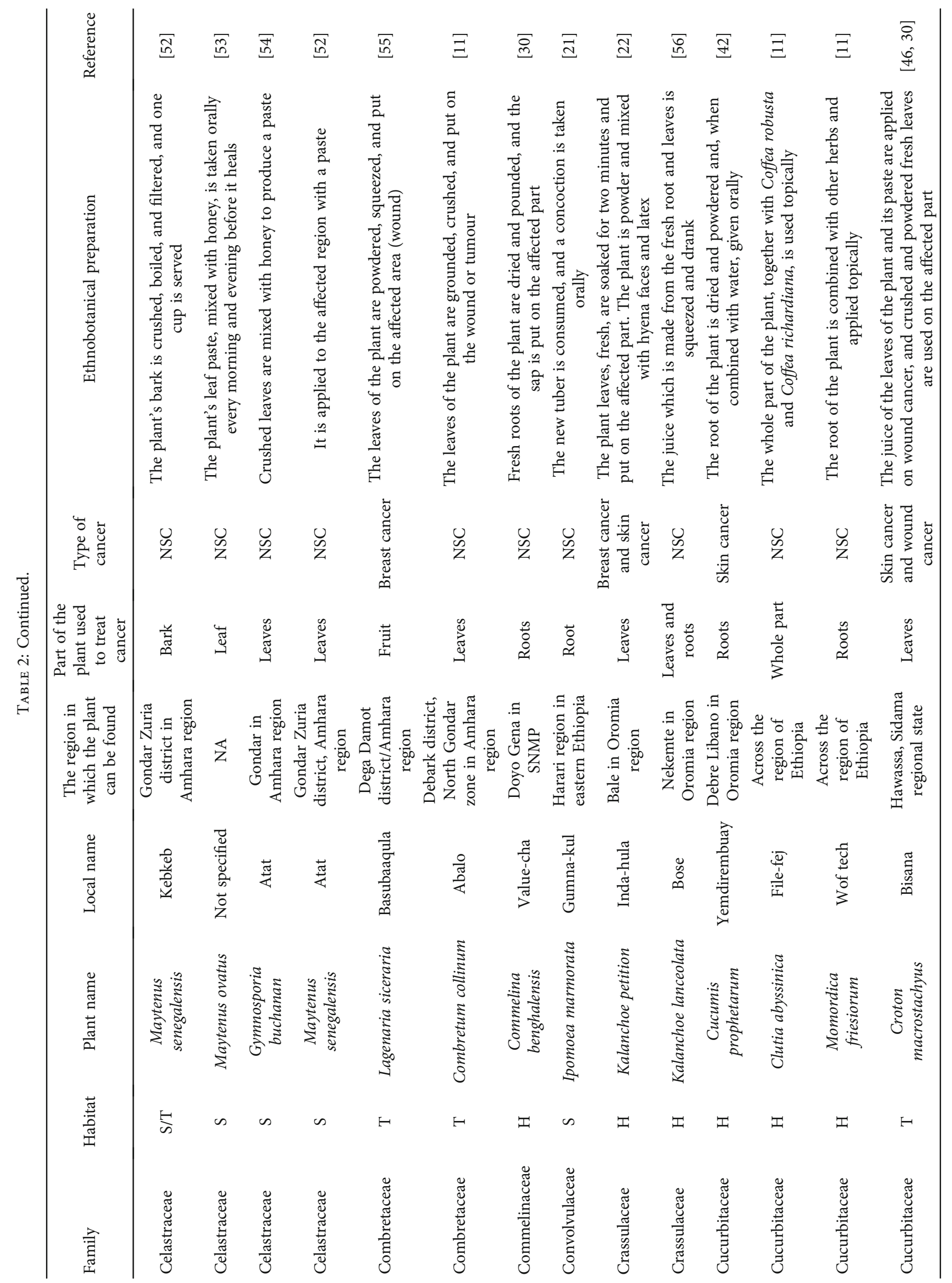




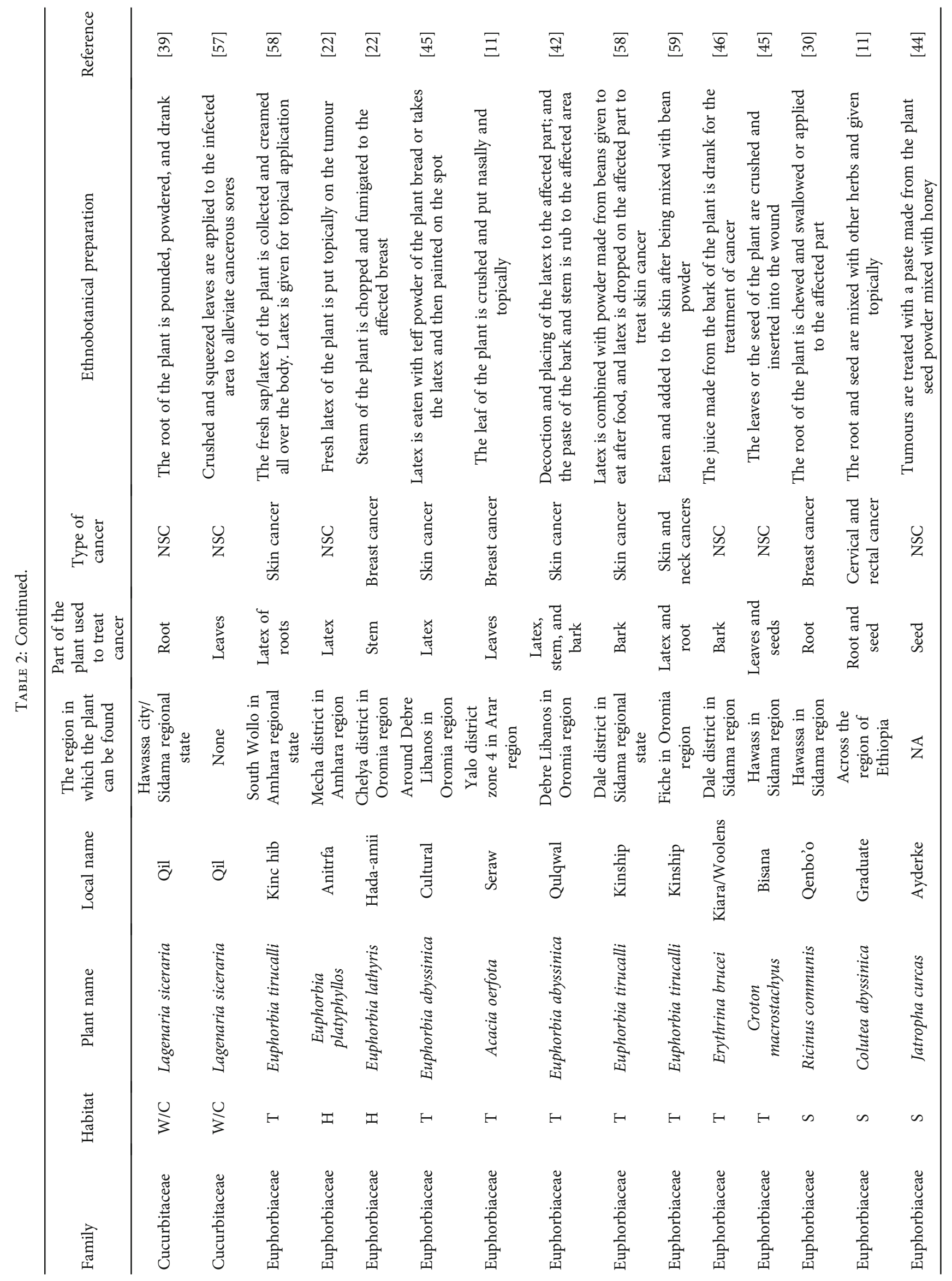




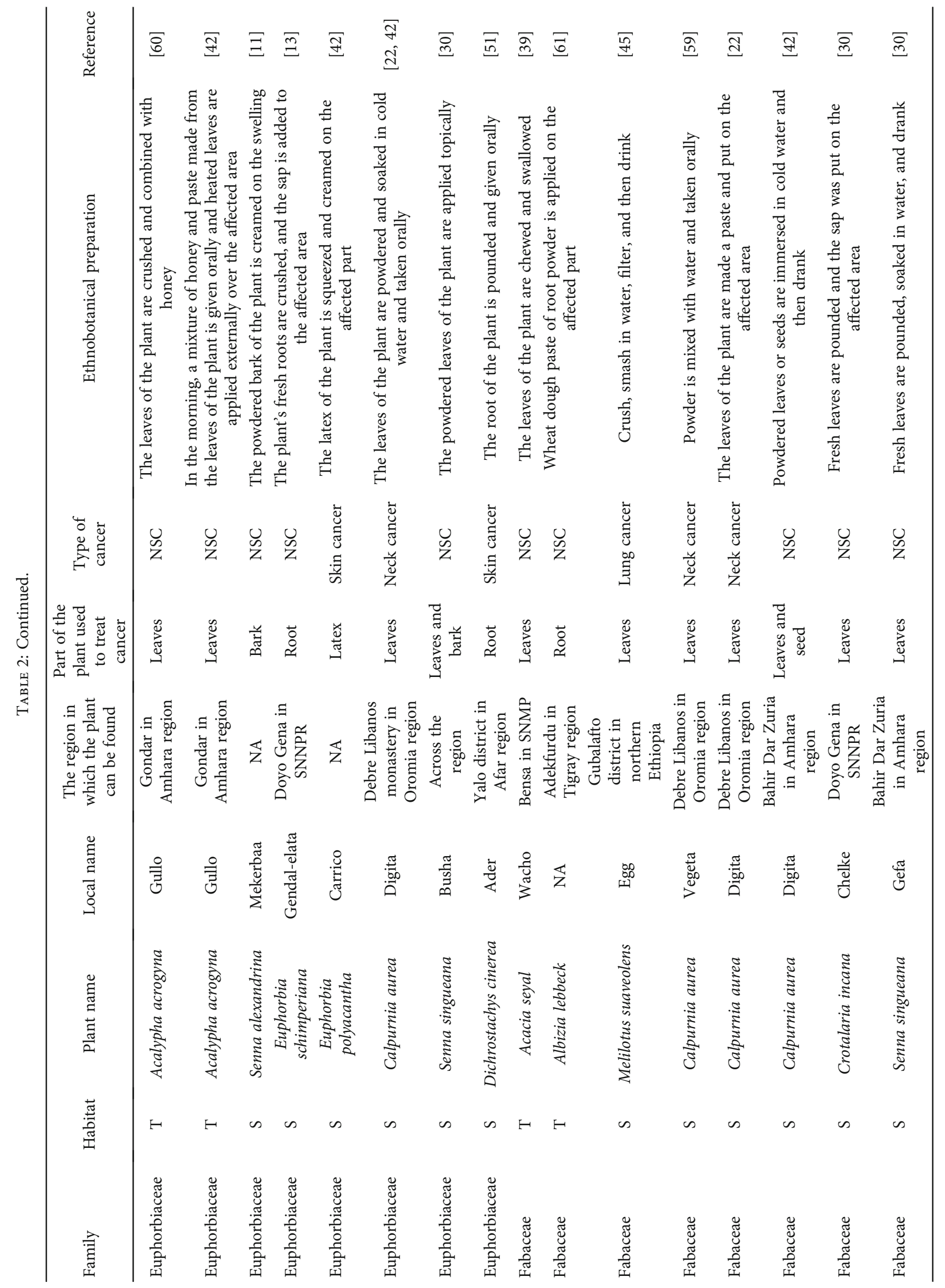




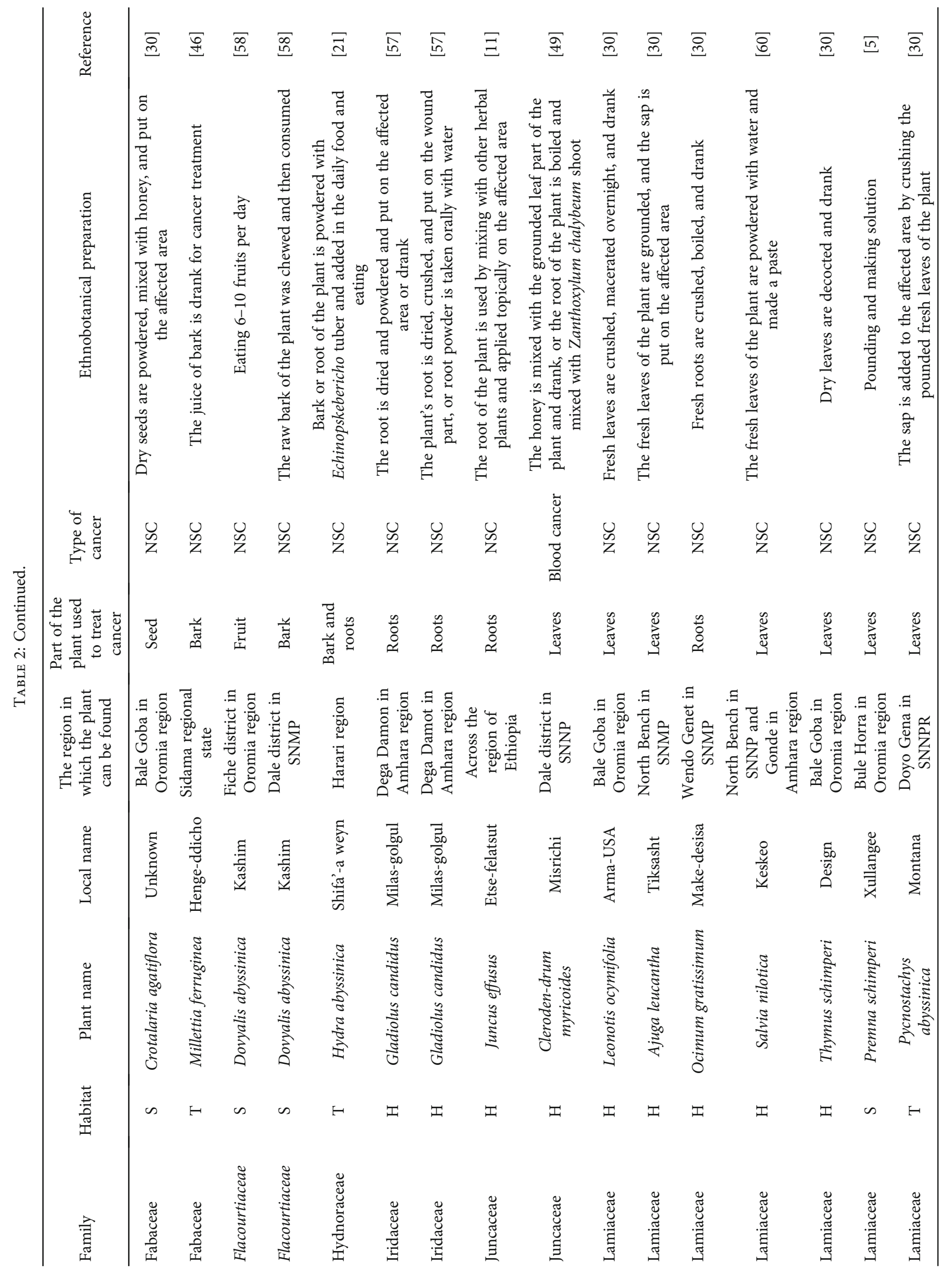




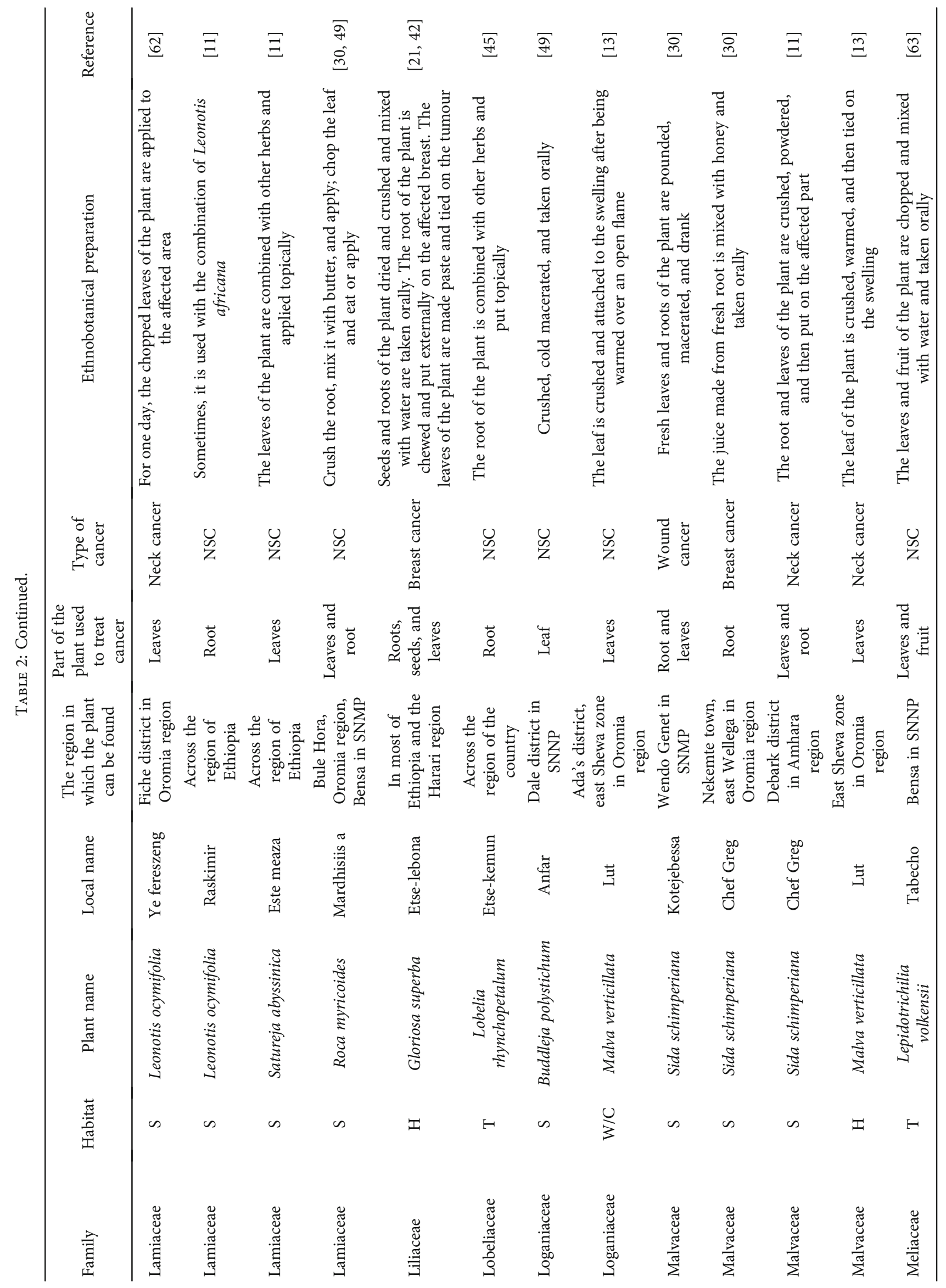




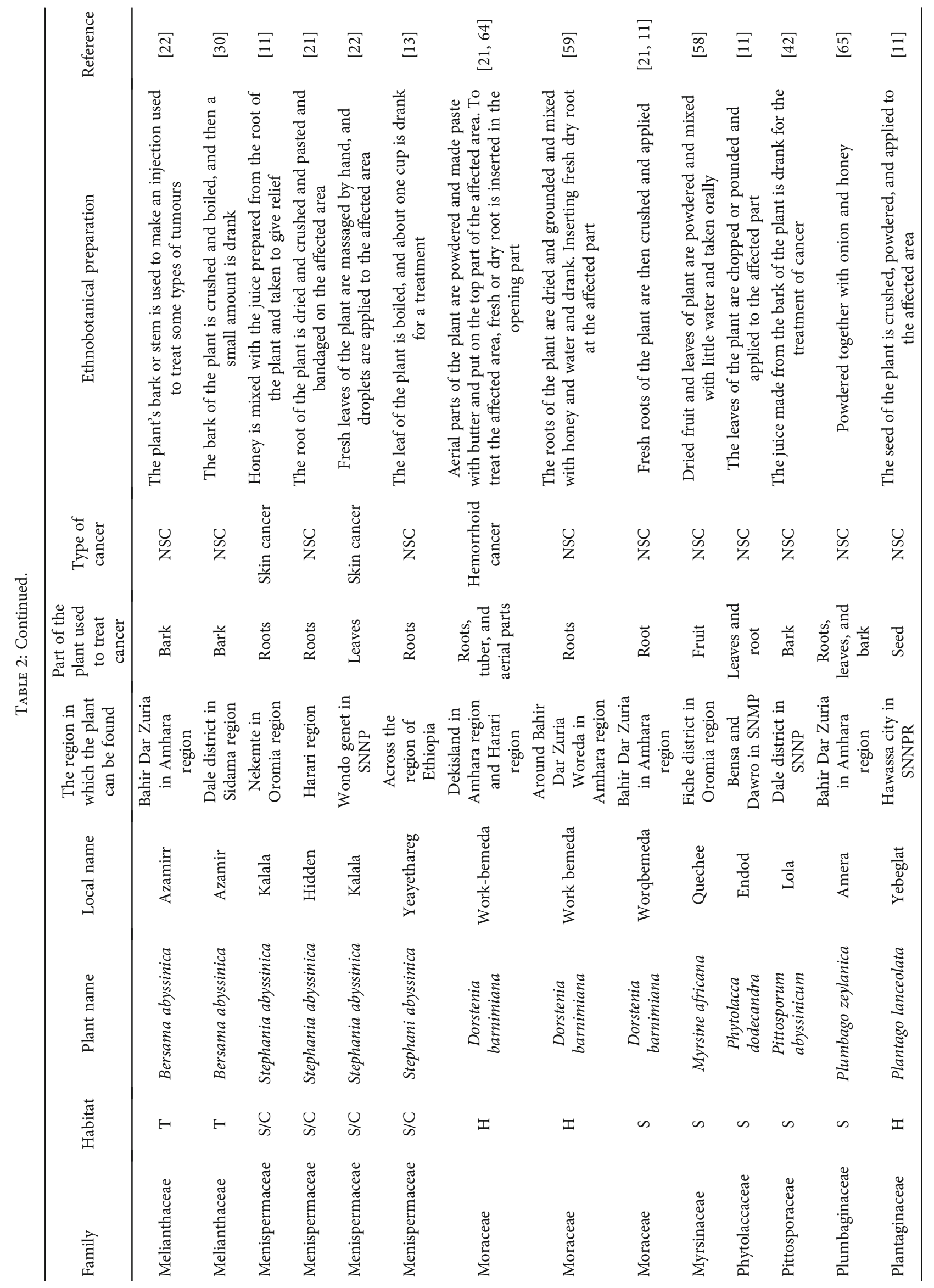




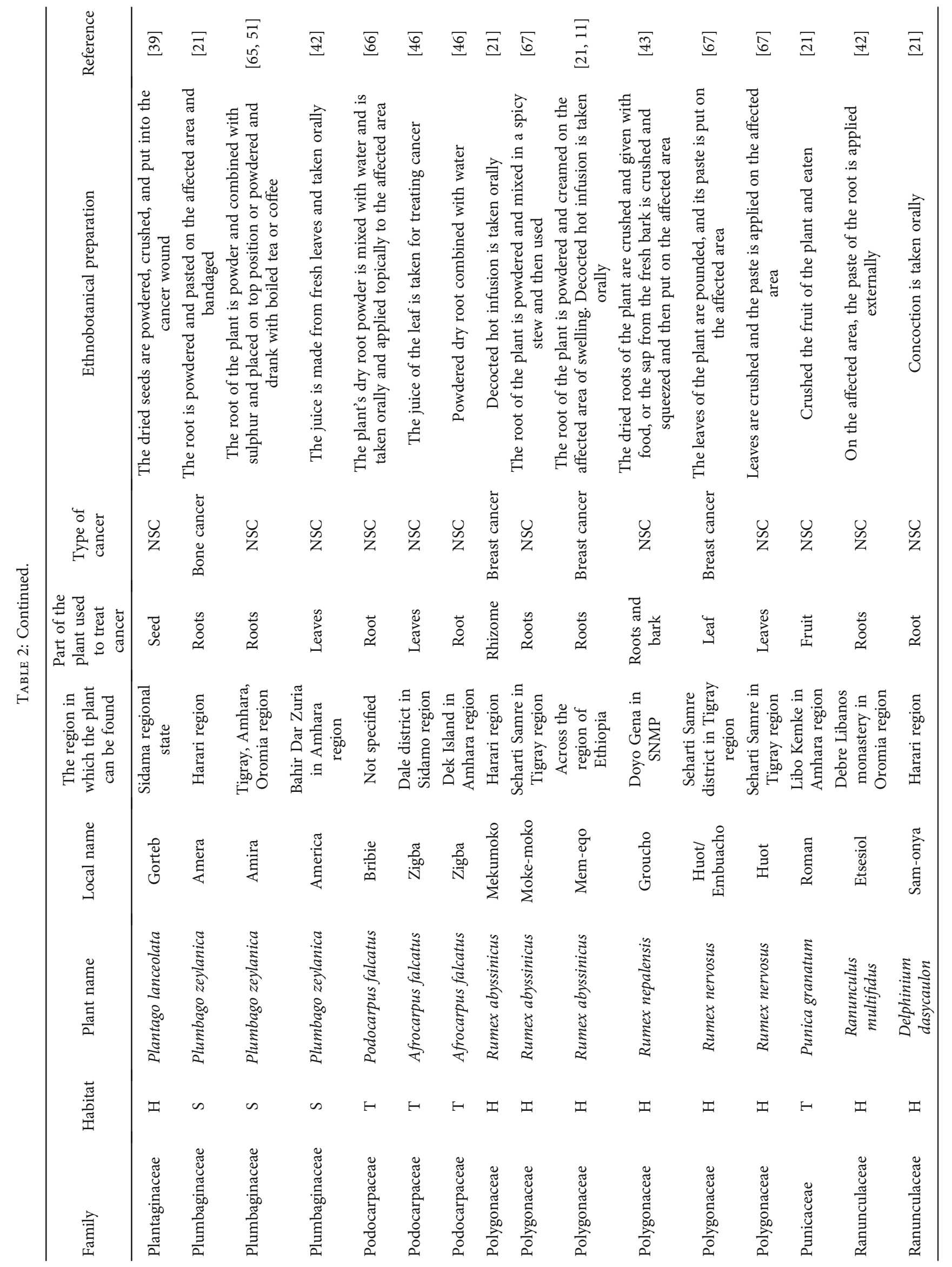




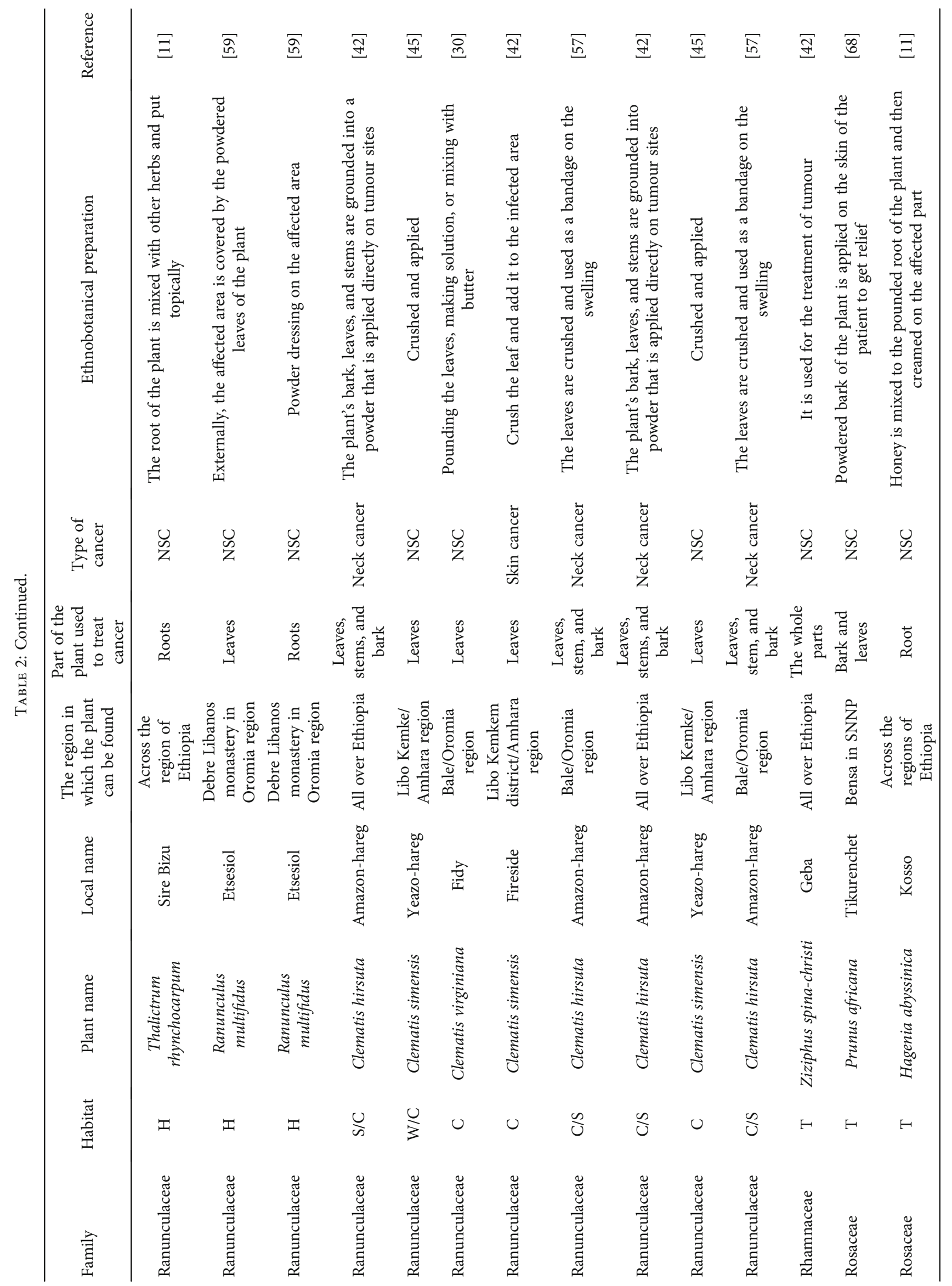




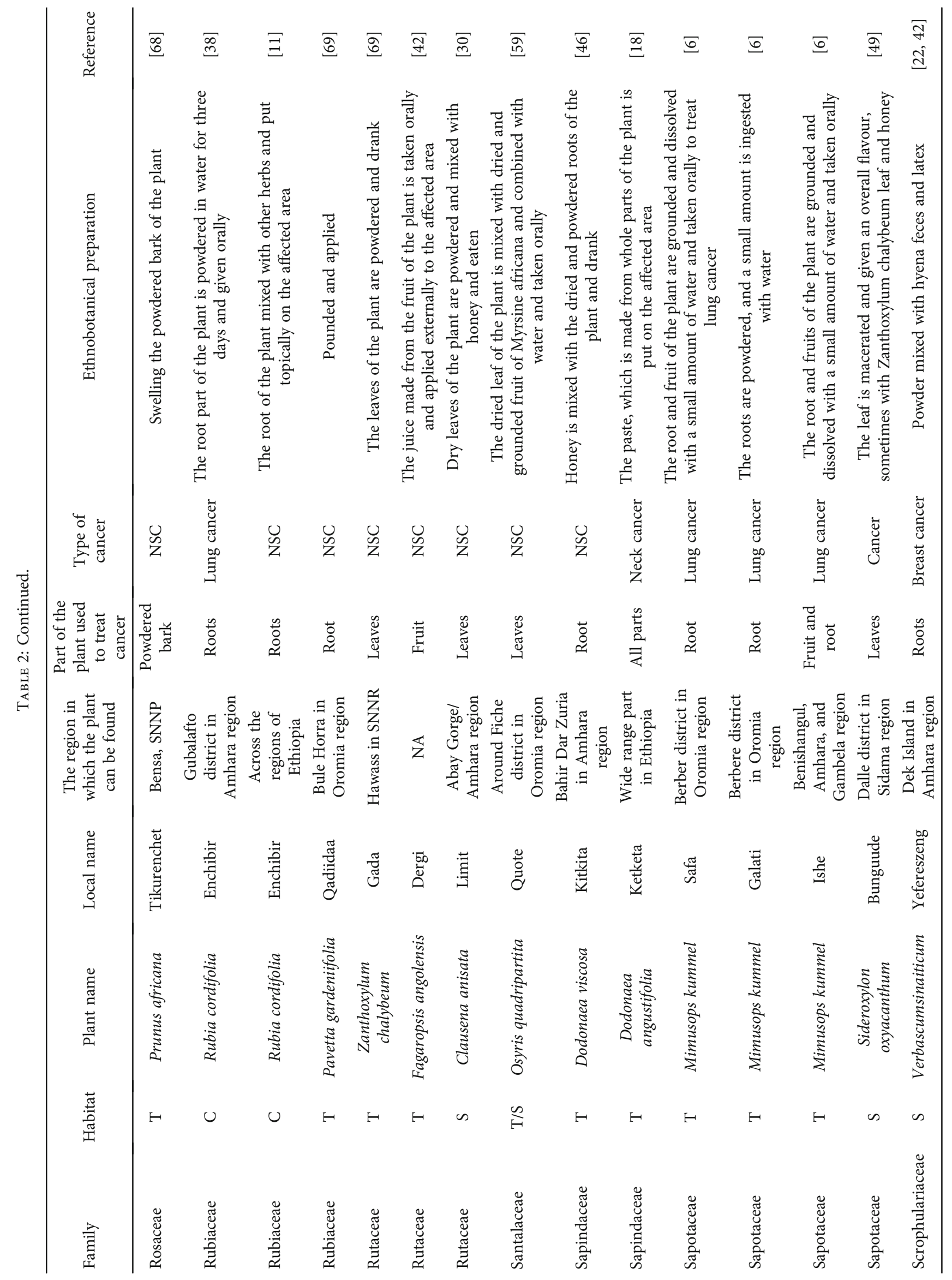




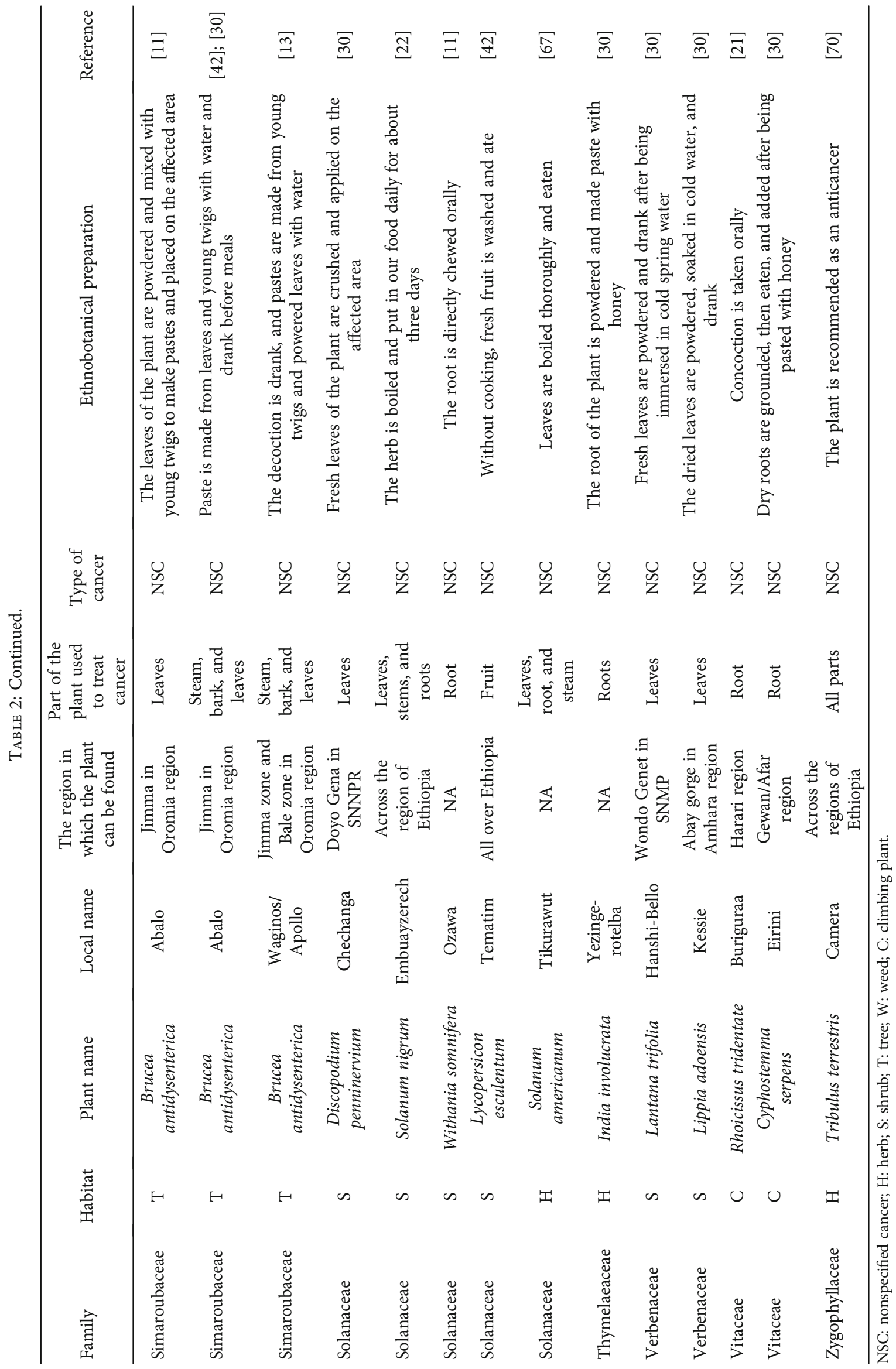




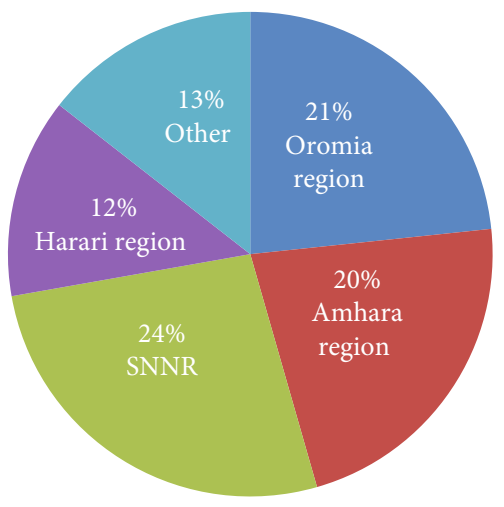

FIgURE 2: Region-wise distribution of anticancer MPs in Ethiopia.

used to make anticancer remedies were leaves (36.76\%), roots $(27.2 \%)$, bark $(12.5 \%)$, stem $(5.1 \%)$, and fruits (7.35\%) (Figures 2 and 3).

\subsection{Pharmacology Activities to Treat Cancer}

3.2.1. Plants Used against Breast Cancer. The most frequent cancer in women worldwide is breast cancer [37]. It is Ethiopia's most common cancer, with high morbidity and mortality rates. The number of new cases increases year to year in the country [71]. According to Memirie et al. [72], of all cancer cases in Ethiopia, 23\% accounts for breast cancer. It accounts for $33 \%$ of the cancers in women. Breast cancer can be treated scientifically using different MPs. Aerva javanica, commonly known as "Tobia," has been confirmed to be used for cancer care. The crude extract from the leaves of Aerva javanica has an antiproliferative effect on human breast cancer cell lines (MCF-7) [73]. Kalanchoe petition, commonly called "indahul," used to cure breast cancer. The gallic acid isolated from the leave of Kalanchoe petition is responsible for its anticancer activity [56]. Extracts of Sideroxylon oxyacanthum are reported to be used frequently against breast cancer [49].

In another study, chloroform extract of aerial part of Clematis simensis was tested for anticancer activity using MTT assay against three breast cancer cell lines (JIMT-1, MCF7 , and MCF-10A). The $\mathrm{IC}_{50}(\mu \mathrm{g} / \mathrm{ml})$ values obtained after treating two breast cancer cell lines (JIMT-1 and MCF-7) and MCF-10A (one normal-like breast epithelial cell line) were as $80 \pm 19,190 \pm 70$, and $97 \pm 9$, respectively [74]. Asparagus africanus, named "Yeset-kest" in the local Ethiopian language, also treats cancer. The roots of the plant have been reported for treating breast tumors [22]. People of various religious and ethnic groups in Ethiopia use Aerva javanica as a traditional medicine to treat multiple diseases, including cancer. A scientifically validated study found that the leaf extracts of Aerva javanica showed an antiproliferative effect on human breast cancer cell lines (MCF-7) [42]. Alkaloids isolated from Catharanthus roseus showed potent cytotoxicity against the MDA-MB-231 breast cancer cell line, with $\mathrm{IC}_{50}$ values ranging from $0.97 \pm 0.07 \mu \mathrm{M}$ to 7.93 $\pm 0.42 \mu \mathrm{M}$ [40]. In another work of Tesfaye and coworkers [75], they checked the cytotoxic activity of Euphorbia schimperiana, Crambe abyssinica, Aloe debrana, Vachellia nilotica,
Camellia sinensis, Termitomyces schimperi, Pentarrhinum insipidum, Acmella caulirhiza, Leonotis ocymifolia, Dorstenia barnimiana, Rumex nervosus, Clausena anisata, Helichrysum mannii, Salvia leucantha, Vernonia auriculifera, Corymbia brachycarpa, and Croton macrostachyus extracts. Out of these, Euphorbia schimperiana, Acokanthera schimperi, Kniphofia foliosa, and Kalanchoe petition showed antiproliferative activity against human breast (MCF-7) cancer cell lines.

3.2.2. Plants Used against Lung Cancer. Lung cancer is the leading cause of cancer-related deaths in men and the second leading cause of cancer-related deaths in women after breast cancer in the world [76]. GLOBOCAN 2020 is an online database providing global cancer statistics and estimates of incidence and mortality in 185 countries for 36 types and all cancer sites combined. According to GLOBOCAN data, there were approximately 18.1 million new cancer cases and 9.6 million deaths worldwide in 2018. Of these, 1.76 million died of lung cancer [77]. In the specified year, the number of new lung cancer cases in Ethiopia is $3.1 \%$ and it accounts for $4.3 \%$ of deaths from the total number of new cancer diseases [20]. Different MPs are used for the prevention and treatment of lung cancer. The seed extracts of Glinus lotoides (n-hexane, chloroform, methanol, and water) were tested for anticancer activity on the lung cancer cell line (Calu-3) using MTT assay. The result showed that methanol extract exhibits the highest anticancer activity with an $\mathrm{IC}_{50}$ value of $29.7 \pm 1.3 \mu \mathrm{g} / \mathrm{mL}$, while water extracts $\left(\mathrm{IC}_{50}=262.2 \pm 1.2 \mu \mathrm{g} / \mathrm{mL}\right)$ exhibit the least anticancer activity [78].

In another study, the anticancer activity of the root of Aloe pirottae was tested against stomach cancer (SNU638), ovarian cancer (A2780), pancreatic cancer (MIA$\mathrm{PaCa}-2$ ), and lung cancer (A549) cell lines. The results demonstrated that all extracts exhibited anticancer activity with an $\mathrm{IC}_{50}$ value ranging from 6.37 to $29.69 \mu \mathrm{g} / \mathrm{mL}$ [79].

The in vitro cytotoxic activity of essential oils and extracts of Ocimum basilicum was tested on a cancerous cell line (MCF-7). The result showed that the cytotoxic activity of essential oil was found to be more effective than that of the extracts [80].

Steroids extracted from Withania somnifera leaves were tested for the lung cancer cell line (NCI-H460). The result showed that steroids exhibited suitable anticancer activities with an $\mathrm{IC}_{50}$ value of $0.45 \mu \mathrm{g} / \mathrm{mL}$ [81]. The cytotoxic activity $\mathrm{T} /$ Corr $(\%)$ of the extract $(50 \mu \mathrm{g} / \mathrm{mL})$ on the lung cancer cell line A427 after 96 hours was tested by Tesfaye et al. [75], with a crystal violet cell proliferation test. According to their research result, Crambe abyssinica, Aloe debrana, and Vachellia nilotica showed values of 29.29, 49.65, 26.76, 26.41, and 46.62 .

3.2.3. Plants against Blood Cancer (Leukemia). Blood-forming stem cells are the source of all blood cells. Blood cancer is caused by defects in the differentiation of these stem cells, which mainly affect white blood cells. Bone marrow transplantation, chemotherapy, antibodies, cytokines, and tumor vaccinations are choices for improving leukemia patients' 

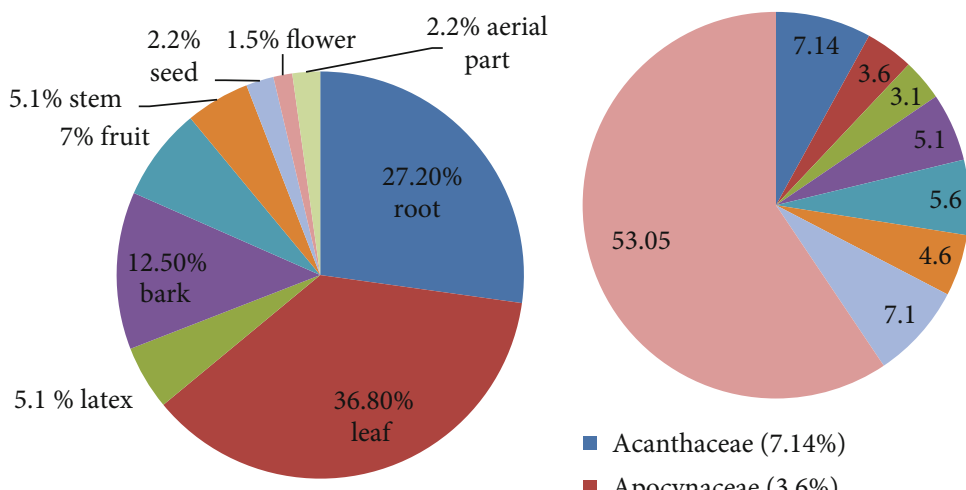

- Acanthaceae (7.14\%)

- Apocynaceae (3.6\%)

- Cucurbitaceae (3.1\%)

- Fabaceae $(5.1 \%)$

n Lamiaceae (5.6\%)

- Podocarpaceae (4.6\%)

- Asteraceae (7.1\%)

- Other (53.05\%)

(a)

(b)

FIgURe 3: (a) Percent usage of different parts of MPs against cancer; (b) family-wise percentage of anticancer MPs.

survival rates [37]. Some Ethiopian plants such as Clerodendrum myricoides, Myrsine melanophloeos, and Solanecio angulatus have demonstrated anticancer activity in the case of leukemia [11]. The flower and leaf extracts of Solanecio angulatus were tested for anticancer activities against HL60 human leukemia cell. The flower extract of the plant showed higher anticancer activities against the cell line with an $\mathrm{IC}_{50}$ value of $27.39 \mu \mathrm{g} / \mathrm{mL}$ [82]. Essential oils of Myrtus communis were reported for the presence of 1,8-cineole, linalool, myrtenyl acetate, and myrtenol which is responsible for its anticancer activity against blood cancer (leukemia) [83]. Methanol and chloroform leaf extracts of Cynoglossum coeruleum were tested for anticancer activities against the HL-60 human leukemia cell line. The result indicated that the methanol extracts showed higher anticancer activity $\left(\mathrm{IC}_{50}=183.95 \mu \mathrm{g} / \mathrm{mL}\right)$ than chloroform extract $(312.62 \mu \mathrm{g} /$ $\mathrm{mL}$ ). The lowest $\mathrm{IC}_{50}$ value was recorded in methanol extract from Cynoglossum coeruleum flower with a value of $360.2 \mu \mathrm{g} / \mathrm{mL}$ [82]. In another study, Jatropha curcas seed extracts displayed potent inhibition against P388 lymphocytic leukemia (both in vitro and in vivo) [42]. One research report showed that Alkaloids isolated from Catharanthus roseus such as vincristine, vinblastine, vindesine, vinorelbine, and vinflunine exhibited cytotoxic activity against human leukemia cells [84]. According to another study, the anticancer activity of crude extracts of Rumex abyssinicus roots was observed in prostate, brain, and breast tumor cell lines and leukemia cell culture [22]. Flavonoids, namely, alpinumisoflavone and $4^{\prime}$-methoxylicoflavanone extracted from Erythrina asuberosa stem bark, were tested for anticancer activity against HL-60 cells (human leukemia) and the result confirmed their anticancer activity [85].

3.2.4. Plants Used against Skin Cancer. The most common cancer in the world is skin cancer. Melanoma is a type of skin cancer that involves basal and squamous cell carcinomas [37]. According to the WHO data from 2017, skin cancer deaths in Ethiopia accounted for 0.03 percent of all deaths. The age-adjusted death rate is 0.37 per 100,000 people of Ethiopia. The most recent WHO data from 2020 also showed that skin cancer deaths in Ethiopia accounted for 0.21 percent of all deaths, with new cases of $0.31 \%$ [86]. Phytochemicals with anti-inflammatory, immune-modulatory, and antioxidant properties have the best chance of acting as a chemopreventive in skin cancers [87]. Scopoletin (7hydroxy-6-methoxy coumarin) from Gelsemium sempervirens has been reported to show anticancer activity against a skin cancer cell line (melanoma A-375) [88]. Plumbagin (a quinonoid constituent) (Figure 4) isolated from the root of Plumbago zeylanica was reported as having anticancer activity [89].

The methanol extract of the leaf of Plantago lanceolata was tested for anticancer activity. The result showed anticancer activities on the UACC-62 cell line with an $\mathrm{IC}_{50}$ value of $50.58 \pm 11.15 \mu \mathrm{g} / \mathrm{mL}[90]$. Triterpenes found from the root of Cucumis prophetarum and gallic acid isolated from leaves of Kalanchoe petitiana are also used to cure skin cancer [90]. Bussa and Belayneh [21] reported the ethnomedicinal use of Vernonia glaberrima leaves and their phytoconstituents against skin cancer. The crude extract obtained from leaves, stems, and barks of Clematis hirsute is used for treating tumor/cancer on the neck [13].

\section{Bioactive Compounds Used for Cancer Treatment}

MPs are the source of many secondary metabolites known for their anticancer activity [37]. Phenolic compounds, alkaloids, glycosides, and terpenoids are some examples of such secondary metabolites with anticancer activity [30]. 


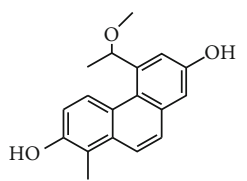

(-) Epigallocathechin5-(1-methoxyethyl)-1-methyl-phenanthren-2,7-diol

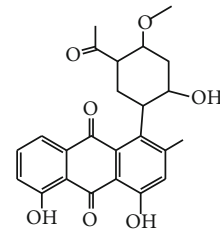

Knipholone

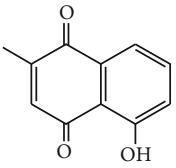

Plumbagin

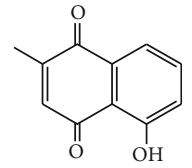

Effususol

FIgURE 4: Anticancer phenolic compounds.

4.1. Phenolic Compound. In plant species, phenolic compounds are formed biologically via flavonoid, phenylpropanoid, and shikimate and possess hydroxide groups in the aromatic ring. These phenolic molecules have been shown for their cytotoxic, antiproliferative, and antioxidant characteristics [91]. Ethiopia has many MPs used to treat cancer; due to the existence of the phenolic molecule, for example, Okoye and coworkers [92] showed the anticancer activity of epigallocatechin extracted from Maytenus senegalensis. The bioactive compounds obtained from Juncus effuses such as 1-methylpyrene-2,7-diol, dehydrojuncusol, dehydroeffusol, effusol, effususol A, and 5-(1-methoxyethyl)-1-methylphenanthrene-2,7-diol (Figure 4) inhibited the proliferation of human cancer cell lines [93, 94]. Naphthoquinone isolated from Plumbago zeylanica extracts also treated human pancreatic and lung cancers $[95,96]$. In another study, isolated compounds knipholone and knipholoneanthrone from Kniphofia foliosa were tested for anticancer activity against leukemic and melanocyte cancer cell lines. The results indicated that knipholoneanthrone has a potential anticancer agent [97].

According to a study on the biological activities and phenolic compounds of ethanolic extracts from Zingiber officinale and Curcuma longa rhizomes, the plants have anticancer properties in the B164A5 murine melanoma cell line due to the presence of phenolic compounds [98].

4.2. Flavonoids. Flavonoids are polyphenolic compounds that make up a broad family of secondary metabolites found in plants [85]. Various research showed that flavonoids in different plants had been used for anticancer activities [99]. Multiple studies have shown that increasing the number of flavonoids in one's diet will reduce cancer risk [100]. Quercetin, chalcones, genistein, curcumin, isoflavones, flavanones, and cisplatin are used to treat human oral cancer while daidzein, genistein, quercetin, luteolin, and flavanones are used to treat human breast cancer. Human lung cancer can be treated with flavone and quercetin [101]. Some flavonols like epicatechin, catechin-3-gallate, epigallocatechin flavan-4-ols, flavan-3, 4-diols, flavan-3-ols, catechin, and gallocatechin also are used to treat different cancers such as prostate and rectal cancers. Flavones such as luteolin, chrysin, apigenin, flavonol: rutin, quercetin, myricetin, kaempferol flavanones: naringenin, hesperidin, eriodictyol, flavanonols: taxifolin are used to take care of lung cancer, laryngeal cancer, and breast cancer [102].

In human leukemia cells, flavonoids extracted from Erythrina suberosa stem bark such as $4^{\prime}$-methoxylicoflavanone and alpinumisoflavone were found to have cytotoxic effects [85]. Flavonoids extracted from Cassia Angustifolia, such as scutellarein, quercimeritrin, and rutin demonstrated considerable anticancer activity against MCF-7, Hep2, and HeLa cell lines, with lower cytotoxicity towards the HCEC cell line [103]. The crude extracts/fractions of Clerodendrum myricoides, Vernonia leopoldi, Dovyalis abyssinica, Sideroxylon oxyacanthum, Clematis longicauda, Zanthoxylum chalybeum, and Clematis simensis were tested for anticancer activities and found cytotoxic effects against various breast cancer-derived cell lines [74].

Bioactive compounds such as luteolin, sesquiterpene lactones, coumarins, and phenolic acids isolated from leaves and shoots of Vernonia amygdalina have shown cancer chemoprevention [44]. One study observed the anticancer activity in Cassia angustifolia extract seed powder against the tested HCEC, Hep2, HeLa, and MCF-7 cell lines. The $\mathrm{IC}_{50}$ value of methanol extract against HeLa cells was $5.45 \mathrm{~g} / \mathrm{L}$ and $4 \mathrm{~g} / \mathrm{L}$ against MCF-7 cells, lower than the drug taxol $6.07 \mathrm{~g} / \mathrm{L}$ and tamoxifen $6.4 \mathrm{~g} / \mathrm{L}$. This anticancer characteristic is due to bioactive flavonoids such as quercimeritrin, scutellarein, and rutin in the plant's seed [104]. The different ethanolic extracts of Lagenaria siceraria were studied for anticancer activity against MCF-7. The result confirmed that it inhibits cancer cells in a concentration-dependent manner with a maximum concentration of $80 \mu \mathrm{g} / \mathrm{mL}$. This anticancer activity of the extract can be attributed to its flavonoid and polyphenol contents in the extracts [55]. Some of the advanced anticancer flavonoids used to treat cancers are myricetin-3-O alpha-Lrhamnopyranoside, flavone-8-acetic acid, quercetin 3-O-D galactopyranoside, chrysoeriol, nobiletin, silybin, flavopiridol, quercetin-3-O-amino acid-esters, xanthone, indirubin, 5,6 dimethylxanthenone-4-acetic acid, diosmetin, and myricetin3-O-alpha-L-rhamnopyranoside (Figure 5) [101]. 
<smiles>Oc1cc(C2Oc3ccccc3C3OC2CCC3O)cc(O)c1O</smiles>

Myricetin-3-O-alpha-L-rhamnopyranoside<smiles>O=C(O)C1CCCC2COCC(c3ccccc3)OC21</smiles>

Flavone-8-Acetic Acid (FAA)<smiles>COc1cc(-c2cc(=O)c3c(O)cc(O)cc3o2)ccc1O</smiles>

Chrysoeriol<smiles>COc1cc(C2OC3C=C(C=CC2O)C2Oc4cc(O)cc(O)c4C(=O)C(O)C2OC3CO)ccc1O</smiles>

Silybin<smiles>N#CC(=O)Oc1c(-c2ccc(O)c(O)c2)oc2cc(O)cc(O)c2c1=O</smiles>

Quercetin -3-O-amino acid-esters

Xanthone

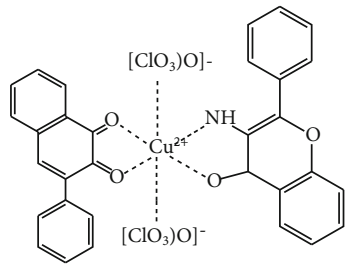

Trans-bis(3-aminoflavone-kappan2N,O bis(perchlorato-kappaO)copper(II)

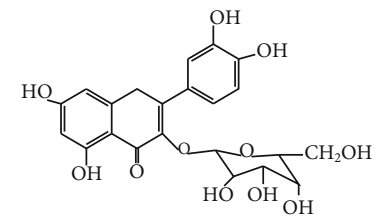

Quercetin 3-O-D-galactopyranoside<smiles>Cc1ccc(C2=CC(C)c3c(C)c(C)c(C)c(C)c3C2)cc1C</smiles>

Nobiletin<smiles>Cc1cc(O)c2c(c1[C@@H]1CCN(C)C[C@@H]1O)OC(c1ccccc1Cl)CC2O</smiles>

Flavopiridol<smiles>Cc1ccc2c(c1C)OC1C(C(=O)O)=CC=CC1C2=O</smiles><smiles>COc1ccc(-c2cc(=O)c3c(O)cc(O)cc3o2)cc1O</smiles>

5,6-dimethyxanthenone-4-acetic acid

Diosmetin

FIgURE 5: Chemical structure of anticancer flavonoids.

4.3. Alkaloids. Alkaloids are essential chemical compounds that can be used to discover new drugs. In vitro and in vivo, some alkaloids derived from natural herbs have antimetastasis and antiproliferative effects on various cancers.
Alkaloids including vinblastine and camptothecin have also been used to develop anticancer drugs [104]. The vinca alkaloids, such as vinblastine, vinorelbine, and vincristine, were the first plant-derived anticancer agents to gain approval 


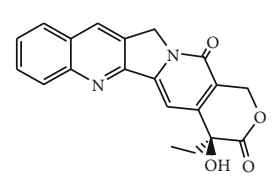

Camptothecin

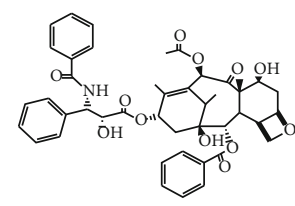

Taxol

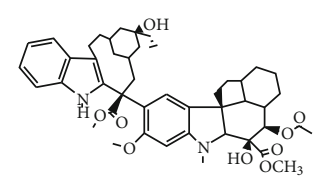

Vinblastine

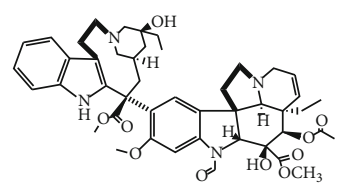

Vincristine<smiles></smiles>

Berberine

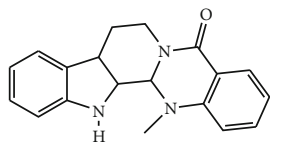

Evodiamine

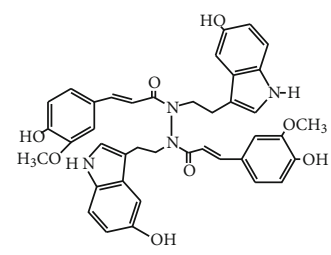

Montamine

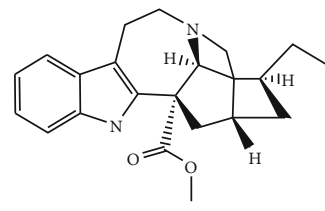

Coronaridine<smiles>O=C1CCCC2C3CCCN4CCCC(CN12)C34</smiles>

Matrine

FIGURE 6: Structure of some anticancer alkaloids.

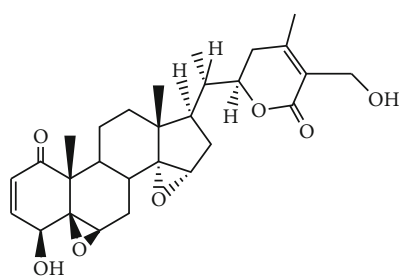

5,6,14,15 diepoxy-4,27-dihydroxy-1-oxowitha-2,24-dienolide

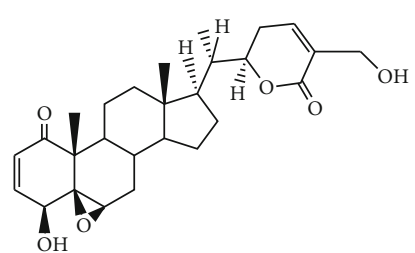

Withaferine-A

FIgURE 7: Structure of anticancer steroids.

for clinical use [87]. Some of the alkaloids used having anticancer activities are taxol, vincristine, vinblastine, 9-methoxycamptothecin, berberine, schischkiniin, coronaridine, naucleaorals, monoamine, camptothecin, an indole alkaloid, and protoberberine [105] (Figure 6). In Ethiopia, the alkaloids extracted from the root of Gloriosa superba are used to treat breast cancer. When the root is chewed and applied externally to the affected area, it relieves and recovers pain [22, 42]. Phytochemical studies conducted in the Harari region have shown that the alkaloids and glycosides in the roots of Hydnora abyssinica are vital for cancer treatment [38]. The chloroform extract of Clematis simensis, rich in alkaloid bioactive compounds, showed cytotoxicity against three breast cancer cell lines. Two breast cancer cell lines JIMT-1 and MCF-7 showed IC I0 $_{50}$ values of $80 \mu \mathrm{g} / \mathrm{mL}$ and $190 \mu \mathrm{g} / \mathrm{mL}$, respectively. One of the normal-like breast epithelial cell lines (MCF-10A) has $97 \mu \mathrm{g} / \mathrm{mL}$ [74]. The alkaloids, which are also present in the flower of Solanecio angulatus, showed in vitro cytotoxicity properties with an $\mathrm{IC}_{50}$ value of $133.72 \mu \mathrm{g} / \mathrm{mL}$ in the tested cell line (HL-60)
[30]. Solasonine and solamargine alkaloid (Figure 6) molecules, which were isolated from Solanum nigrum, exhibited anticancer activities on the human gastric cancer cell line (MGC-803) with $\mathrm{IC}_{50}$ values of $5.2 \mu \mathrm{g} / \mathrm{mL}$ and $8.77 \mu \mathrm{g} / \mathrm{mL}$, respectively [40].

4.4. Steroids. A group of natural or synthetic organic compounds with a molecular structure of 17 carbon atoms grouped in four rings is known as steroids. In genetics, chemistry, and medicine, steroid hormones play a significant role. Hundreds of steroids have been discovered in fungi, animals, and plants [106]. Medicinal plant steroids are well-known secondary metabolites to have anticancer activity [107]. Bioactive compounds of steroids which were isolated from Withania somnifera such as 5,6,14,15 diepoxy4,27-dihydroxy-1-oxowitha-2,24-dienolide and withaferinA (Figure 7) showed anticancer activity to the human lung cancer cell line (NCI-H460) with $0.45 \mu \mathrm{g} / \mathrm{mL}$ and $8.3 \mu \mathrm{g} /$ $\mathrm{mL} \mathrm{IC}_{50}$ values, respectively, [81]. In addition, cytotoxic activities were shown in extracts of Bersama abyssinica. 

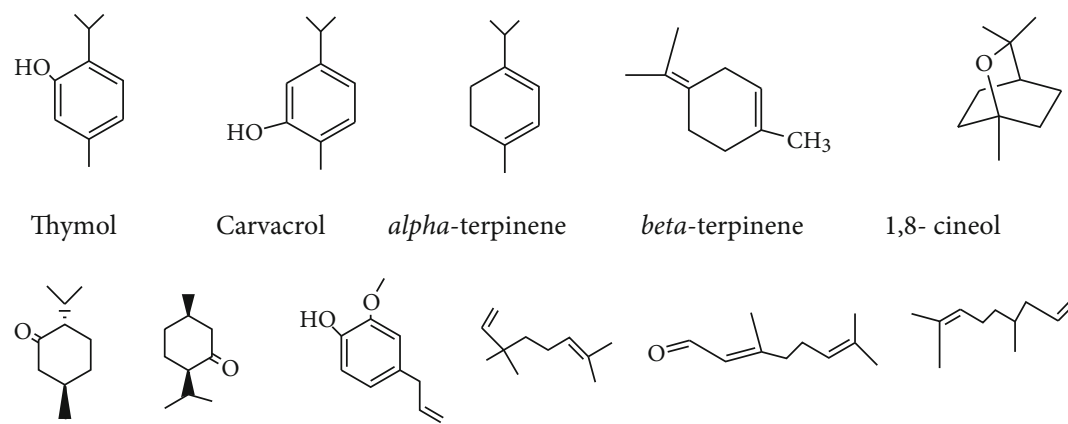

Carvacrol

alpha-terpinene

beta-terpinene

1,8- cineol

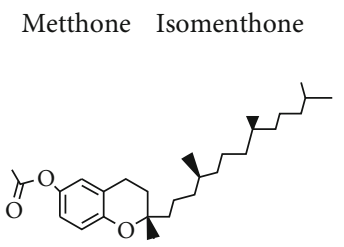

Eugenol

linalool

Citral

Citronellal
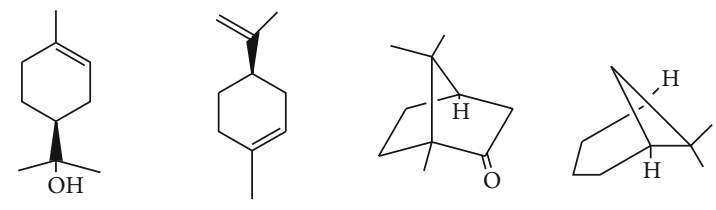

alpha-tocopheryl acetate

alpha-terpineol

d-limonene camphor

alpha-pinenol

Figure 8: Anticancer components from different essential oil.

Hellebrigenin 3,5 diacetate, hellebrigenin 3-acetate, bersenogenin, 3-epiberscillogenin, and berscillogenin demonstrated cytotoxic activities in the plant extract [108, 109]. Physalin B, D, F steroids which are found in Physalis angulate showed anticancer activities on different cancer cell lines such as $\mathrm{KB}$, A549, HCT8, and PC3 with the lowest $\mathrm{EC}_{50}(\mu \mathrm{g} / \mathrm{mL})$ value of 0.9 (for KB), 1.3 (for A549), 1.0 (for HCT8), and 0.9 (for PC3), respectively, for physalin F, physalin D, and physalin B [110].

4.5. Essential Oil. Essential oils (EOs) are well-known anticancer bioactive compounds obtained from medicinal and aromatic plants. Essential oils are highly volatile, aromatic yields obtained from plants. Due to their volatility, they can easily be extracted by steam distillation from different natural sources [111]. They may be a generic word for the liquid and highly volatile plant constituents with a distinct odor [111]. EOs having anticancer properties are listed in Figure 8 . They are present in plants as secondary metabolites in their flowers, leaves, fruits, buds, seeds, rhizomes, barks, and roots $[112,113]$. The essential oils such as limonene and perillyl alcohol, which is extracted from Citrus sinensis, are used for anticancer activities [114], and terpinene-4-ol, $\alpha$-thujone, $\beta$-citronellal, $\alpha$-pinene, $\gamma$-eudesmol, $\delta$-cadinene, and methyl cinnamate from the Lamiaceae family are used for anticancer activities [115] as illustrated in Figure 8. The presence of bioactive compounds such as citronellyl acetate, pulegol, and citronellol in essential oils from Pulicaria inuloides was used for anticancer activity against liver, breast, and colorectal/colon cancers [116]. The essential oils derived from the flower of Achillea ligustica, leaf and the seed of Coriandrum sativum, leaf of Melaleuca alternifolia, the seed of Nigella sativa, and aerial parts of Pelargonium graveolens are used to treat different cancer diseases [117]. Some bioactive compounds such as linalool, 1,8-cineole, myrtenyl acetate, and myrtenol in Myrtus communis essential oil have anticancer properties in the case of blood cancer (leukemia) [83].

4.6. Other Bioactive Compounds. Various studies have shown that bioactive compounds such as fucoxanthin can be used to prevent breast cancer and triterpenes, anthocyanins, and saponins can be used to treat lung cancer. Blood cancer can be prevented using epigallocatechin gallate and rosavin [118]. Various compounds have been isolated from Bersama abyssinica to determine the plant's anticancer or antitumor function. Lignin and hallebergenin 3-acetate are two of these compounds that have been shown to inhibit tumor growth [22]. Garcinol, limonoids, crocin, and genistein are used to prevent pancreatic cancer [118]. The root of India involucrate, also known as "Yezngerotelba" in Amharic, can treat cancer, including diterpenes, and gnidicin, mezerein, gnidilatidin, gnidiglucin, and gniditrin are used to prevent cancer isolation biologically active compounds [22]. Boswellia acids in boswellia species give a defense mechanism to have anticancer activities [119]. The presence of gallic acid isolated from the leaves of Kalanchoe petition, which is commonly called "indahula," is also essential to cure breast cancer [56]. It has been documented that the roots of Asparagus africanus are used to treat tumors [22]. Three lignans isolated from Carissa spinarum, namely, nortrachelogenin, carol, and carissanol, were found to be cytotoxic to WI38, MCF7, and A549 cell lines. Compared with carissanol and nortrachelogenin, carinol shows higher cytotoxic activity against these three cell lines, with an $\mathrm{IC}_{50}$ value of $1 \mu \mathrm{g} / \mathrm{mL}$ [40].

\section{Conclusion and Future Perspective}

Several plant species are already being utilized to treat or prevent cancer. Multiple studies have identified plant species with 
anticancer characteristics, emphasizing herbal medicine in developing nations. In Ethiopia, many MPs can treat various types of cancer, such as breast cancer, lung cancer, blood cancer, and skin cancer and tumors. The ethnobotanical application of MPs for cancer treatment confirmed that plant leaves are the most valuable for preparing anticancer drugs (36.76\%), followed by roots (27.2\%), bark (12.5\%), and flowers (1.5\%). According to the analyzed data, the Euphorbiaceae family has the highest percentage $(10.71 \%)$ of plant families utilized to treat cancer. The Asteraceae and Lamiaceae families have the second $(7.1 \%)$ and third (6.1\%) values, respectively. Regarding their habit, shrubs account for (39.5\%) followed by herbs (33.8\%), trees (17.9\%), and climber or weed $(8.8 \%)$.

Although numerous MPs have been utilized ethnobotanically to treat cancer, only a few MPs have been formally examined for anticancer activity. A few secondary metabolites and pure isolated compounds have been tested against cancer cell lines in vitro. Therefore, it is imperative to conduct detailed phytochemical research to isolate new anticancer drugs. Since the traditional knowledge for anticancer medicines provides basic information for further scientific research on the synthesis of anticancer drugs, it is necessary to conduct comprehensive ethnomedicinal research. The anticancer mechanism of these medicinal plant extracts is still unclear. Therefore, more in-depth scientific research is needed, which is the homework for researchers to conduct further studies.

\section{Abbreviations}

$\begin{array}{ll}\text { AIF: } & \text { Alpinumisoflavone } \\ \text { FAA: } & \text { Flavone-8-acetic acid } \\ \text { MLF: } & 4^{\prime} \text {-Methoxylicoflavanone } \\ \text { MP: } & \text { Medicinal plant } \\ \text { MTT: } & \text { 3-(4,5-Dimethylthiazol-2-yl)-2,5-diphenyl-2H- } \\ & \text { tetrazolium } \\ \text { SRB assay: } & \text { Sulforhodamine B } \\ \text { EOs: } & \text { Essential oil } \\ \text { NSC: } & \text { Nonspecified cancer } \\ \text { SNNP: } & \text { Southern Nations, Nationalities, and peoples } \\ \text { TMs: } & \text { Traditional medicines } \\ \text { WHO: } & \text { World Health Organization. }\end{array}$

\section{Conflicts of Interest}

The authors declare that they have no competing interests.

\section{Authors' Contributions}

LA and MG drafted the review. AB prepared the different tables and figures required for the manuscript. RKB provided guidance during the development of the idea and wrote and revised the manuscript. The authors read and approved the final manuscript.

\section{References}

[1] L. Abate, A. Bachheti, R. K. Bachheti, and A. Husen, "Potential role of forest-based plants in essential oil production: an approach to cosmetic and personal health care applications," in Non-Timber Forest Products, A. Husen, R. K. Bachheti, and A. Bachheti, Eds., Springer, Cham, 2021.

[2] Y. H. Gonfa, F. Beshah, M. G. Tadesse, A. Bachheti, and R. K. Bachheti, "Phytochemical investigation and potential pharmacologically active compounds of Rumex nepalensis: an appraisal," Journal of Basic and Applied Sciences, vol. 10, no. 1, pp. 1-11, 2021.

[3] F. Beshah, Y. Hunde, M. Getachew, R. K. Bachheti, A. Husen, and A. Bachheti, "Ethnopharmacological, phytochemistry and other potential applications of _Dodonaea_ genus: A comprehensive review," Current Research in Biotechnology, vol. 2, pp. 103-119, 2020.

[4] A. Sharma, A. Bachheti, P. Sharma, R. K. Bachhetiand, and A. Husen, "Phytochemistry, pharmacological activities, nanoparticle fabrication, commercial products and waste utilization of Carica papaya L.: A comprehensive review," Current Research in Biotechnology, vol. 2, pp. 145-160, 2020.

[5] H. Yuan, Q. Ma, L. Ye, and G. Piao, "The traditional medicine and modern medicine from natural Products," Molecules, vol. 21, no. 5, p. 559, 2016.

[6] T. Jimaand and M. Megersa, "Ethnobotanical study of medicinal plants used to treat human diseases in Berbere District, Bale Zone of Oromia Regional State, South East Ethiopia," Evidence-Based Complementary and Alternative Medicine, vol. 2018, Article ID 8602945, 2018.

[7] S. Adebayo, M. Ondua, L. Shai, and S. Lebelo, "Inhibition of nitric oxide production and free radical scavenging activities of four South African medicinal plants," Journal of Inflammation Research, vol. Volume 12, pp. 195-203, 2019.

[8] S. Fayera, N. Babu G, A. Dekebo, and Y. Bogale, "Phytochemical investigation and antimicrobial study of leaf extract of Plantago lanceolata," Natural Product Research, vol. 6, no. 2, pp. 1-8, 2018.

[9] Y. Ahmed, K. Muhammedawel, and D. Ashebir, "Knowledge, attitude and practice of community on traditional medicine in Jara town, Bale Zone South East Ethiopia," Journal of Public Health, vol. 4, no. 3, p. 241, 2016.

[10] M. Mengistu, D. Kebede, D. Atomsa, A. Abebe, and D. Alemnie, "Status and utilization of medicinal and aromatic plants in Eastern Hararghe, Ethiopia," Cogent Food and Agriculture, vol. 5, no. 1, pp. 1-27, 2019.

[11] N. Tuasha, B. Petros, and Z. Asfaw, "Plants used as anticancer agents in the Ethiopian traditional medical practices: A systematic review," Evidence-Based Complementary and Alternative Medicine, vol. 2018, Article ID 6274021, 28 pages, 2018.

[12] T. Asmare, B. Yilkal, T. Mekuannint, and A. Yibeltal, "Traditional medicinal plants used to treat maternal and child health illnesses in Ethiopia: An Ethno-botanical approach," Journal of Traditional Medicine and Clinical Naturopathy, vol. 7, no. 3, pp. 1-10, 2018.

[13] A. Moges and Y. Moges, "Ethiopian common medicinal plants. Their parts and uses in traditional medicine - ecology and quality control," in Plant Science - Structure, Anatomy and Physiology in Plants Cultured in Vivo and in Vitro, IntechOpen, 2020.

[14] M. Adoma, M. Tahera, M. Mutalabisina et al., "Chemical constituents and medical benefits of Plantago major," Biomedicine and Pharmacotherapy, vol. 96, pp. 348-360, 2017.

[15] A. Dalar, M. Turker, and I. Konczak, "Antioxidant capacity and phenolic constituents of Malva neglecta Wallr. and 
Plantago lanceolata L. from Eastern Anatolia Region of Turkey," Journal of Herbal Medicine, vol. 2, no. 2, pp. 42-51, 2012.

[16] L. Othman, A. Sleiman, and R. Abdel-Massih, "Antimicrobial activity of polyphenols and alkaloids in Middle Eastern plants," Frontiers in Microbiology, vol. 10, no. 911, pp. 1-28, 2019.

[17] P. Garcia-Oliveira, P. Otero, A. G. Pereira et al., "Status and challenges of plant-anticancer compounds in cancer treatment," Pharmaceuticals, vol. 14, no. 2, p. 157, 2021.

[18] A. Bruni, "Non-communicable diseases. Cancer - a growing public health concern for Ethiopia. Activities of the genus Aerva: a desert plant," Acta Poloniae Pharmaceutica Drug Research, vol. 69, pp. 67-77, 2012.

[19] M. Woldu, D. Legese, and F. Abamecha, "The prevalence of cancer and its associated risk factors among patients visiting Oncology unit, Tikur Anbessa Specialized Hospital, Addis Ababa- Ethiopia," Journal of Cancer Sciences and Therapy, vol. 9, no. 4, pp. 1-8, 2017.

[20] WHO, Number of new cases in 2018, both sexes, all ages. internation agency for research of cancer, Globocan, 2020, https:// gco.iarc.fr/today/data/factsheets/populations/231-ethiopiafact-sheets.pdf.

[21] N. Bussa and A. Belayneh, "Traditional medicinal plants used to treat cancer, tumors and inflammatory ailments in Harari Region, Eastern Ethiopia," South African Journal of Botany, vol. 122, pp. 360-368, 2019.

[22] W. Abebe, "An overview of Ethiopian traditional medicinal plants used for cancer treatment," European Journal of Medicinal Plants, vol. 14, no. 4, pp. 1-16, 2016.

[23] R. Agbaria, A. Gabarin, A. Dahan, and S. Ben-Shabat, "A nticancer activity of Nigella sativa (black seed) and its relationship with the thermal processing and quinone composition of the seed," Drug Design, Development and Therapy, vol. 9, pp. 3119-3124, 2015.

[24] M. Akhbari, R. Kord, S. Nodooshan, and S. Hamedi, "Analysis and evaluation of the antimicrobial and anticancer activities of the essential oil isolated fromFoeniculum vulgarefrom Hamedan, Iran," Natural Product Research, vol. 33, no. 11, pp. 1629-1632, 2019.

[25] E. Abdel-Hameed, S. Bazaid, O. al Zahrani, Y. el-Halmouch, M. M. el-Sayed, and E. el-Wakil, "Chemical composition of volatile components, antimicrobial and anticancer activity of n-hexane extract and essential oil from trachyspermum ammi L. Seeds," Oriental Journal of Chemistry, vol. 30, no. 4, pp. 1653-1662, 2014.

[26] L. Alobaidi, "Study the anticancer effect of Lepidium sativum leaves extract on Squamous Cell Carcinoma (CAL-27) cell lines," Journal of Natural Sciences Research, vol. 4, no. 17, pp. 48-52, 2014.

[27] B. Marongiu, A. Piras, S. Porcedda, and A. Scorciapino, "Chemical composition of the essential oil and supercritical $\mathrm{CO}_{2}$ extract of Commiphora myrrha (Nees) Engl. and of Acorus calamus L.," Journal of Agricultural and Food Chemistry, vol. 53, no. 20, pp. 7939-7943, 2005.

[28] O. Lengliz, J. Mejri, M. Abderrabba, R. Khalifa, and M. Mejri, "Ruta chalepensis L. Essential oil: A new antisprouting agent for potatoes bioconservation," Journal of Chemistry, vol. 2018, Article ID 8547851, 6 pages, 2018.

[29] A. Kasali, O. Ekundayo, P. Winterhalter, W. Koenig, and A. Eshilokun, "Chemical constituents of the essential oil
ofLippia adoensis Hochst. ex Walp," Flavour and Fragrance Journal, vol. 19, no. 3, pp. 210-212, 2004.

[30] S. TEsubalew, A. Belete, E. Lulekal, and T. Gabriel, "Review of ethnobotanical and ethnopharmacological evidences of some Ethiopian medicinal plants traditionally used for the treatment of cancer," Ethiopian Journal of Health Development, vol. 31, no. 3, pp. 161-187, 2017.

[31] E. Birhane, E. Aynekulu, and W. Mekuria, "Management, use and ecology of medicinal plants in the degraded dry lands of Tigray, Northern Ethiopia," Journal of Medicinal Plant Research, vol. 5, no. 3, pp. 308-319, 2011.

[32] Y. Woldeamanuel, B. Girma, and A. Teklu, "Cancer in Ethiopia," The Lancet Oncology, vol. 14, no. 4, pp. 289290, 2013.

[33] S. Solomon and W. Mulugeta, "Diagnosis and risk factors of advanced cancers in Ethiopia," Journal of Cancer Prevention, vol. 24, no. 3, pp. 163-172, 2019.

[34] WHO, "International agency for research on cancer, Ethiopia source," Globocan, 2020.

[35] M. Sisay, N. Bussa, T. Gashaw, and G. Mengistu, "Investigating in vitro antibacterial activities of medicinal plants having folkloric repute in Ethiopian traditional medicine," Journal of Evidence-Based Integrative Medicine, vol. 24, article 2515690X1988627, 2019.

[36] F. O. Ohiagu, P. C. Chikezie, C. M. Chikezie, and C. E. Enyoh, "Anticancer activity of Nigerian medicinal plants: a review," Future Journal of Pharmaceutical Sciences, vol. 7, no. 1, pp. 1-21, 2021.

[37] M. F. Akhtar, A. Saleem, Alamgeer, and M. Saleem, "A Comprehensive review on ethnomedicinal, pharmacological and phytochemical basis of anticancer medicinal plants of Pakistan," Current Cancer Drug Targets, vol. 19, no. 2, pp. 120151, 2019.

[38] G. Bekele and P. Reddy, "Ethnobotanical study of medicinal plants used to treat human Ailments by Guji Oromo tribes in Abaya district, Borana, Oromia, Ethiopia," Universal Journal of Plant Science, vol. 3, no. 1, pp. 1-8, 2015.

[39] R. Regassa, "Assessment of indigenous knowledge of medicinal plant practice and mode of service delivery in Hawassa city, southern Ethiopia," Journal of Medicinal Plant Research, vol. 7, no. 9, pp. 517-535, 2013.

[40] S. Tesfaye, K. Asres, E. Lulekal et al., "Ethiopian medicinal plants traditionally used for the treatment of cancer, part 2: A review on cytotoxic, antiproliferative, and antitumor phytochemicals, and future perspective," Molecules, vol. 25, no. 17, p. 4032, 2020.

[41] D. Kamalanathan and D. Natarajan, "Anticancer potential of leaf and leaf-derived callus extracts of Aerva javanica against MCF-7 breast cancer cell line," Journal of Cancer Therapy Research, vol. 9, pp. 215-226, 2013.

[42] T. Ayele, "A review on traditionally used medicinal plants/ herbs for cancer therapy in Ethiopia: current status, challenge and future perspectives," Organic Chemistry: Current Research, vol. 7, no. 2, pp. 1-8, 2018.

[43] G. Chekole, Z. Asfaw, and E. Kelbessa, "Ethnobotanical study of medicinal plants in the environs of Tara-gedam and Amba remnant forests of Libo Kemkem District, northwest Ethiopia," Journal of Ethnobiology and Ethnomedicine, vol. 11, no. 1, pp. 1-38, 2015.

[44] M. Agize, S. Demissew, and Z. Asfaw, "Ethnobotany of medicinal plants in Loma and Gena Bosa districts (woredas) 
of Dawro zone, southern Ethiopia," Topclass Journal of Herbal Medicine, vol. 2, no. 9, pp. 194-212, 2013.

[45] G. Chekole, "Ethnobotanical study of medicinal plants used against human ailments in Gubalafto District, Northern Ethiopia," Journal of Ethnobiology and Ethnomedicine, vol. 13, no. 1, pp. 1-29, 2017.

[46] G. Kewessa, T. Abebe, and A. Demissie, "Indigenous knowledge on the use and management of medicinal trees and shrubs in Dale District, Sidama Zone, Southern Ethiopia," Ethnobotany Research and Applications, vol. 14, pp. 171182, 2015.

[47] N. Wabe, M. Mohammed, and N. Raju, “An ethnobotanical survey of medicinal plants in the Southeast Ethiopia used in traditional medicine," Spatula DD, vol. 1, no. 3, pp. 153$155,2011$.

[48] A. Meresa, W. Gemechu, H. Basha et al., "Herbal medicines for the management of diabetic mellitus in Ethiopia and Eretria including their phytochemical constituents," American Journal of Advanced Drug Delivery, vol. 5, no. 1, pp. 40-58, 2017.

[49] N. Tuasha, B. Petros, and Z. Asfaw, "Medicinal plants used by traditional healers to treat malignancies and other human ailments in Dalle District, Sidama Zone, Ethiopia," Journal of Ethnobiology and Ethnomedicine, vol. 14, no. 1, pp. 1-21, 2018.

[50] Adigrat University Department of Biology and A. B. Feto Haji, "Ethnobotanical study of medicinal plants used for the treatment of human and livestock ailments in Dawe Kachen District of Bale Zone, Southeast Ethiopia," Journal of Natural Remedies, vol. 4, no. 4, pp. 5043-5055, 2017.

[51] T. Teklehaymanot, "An ethnobotanical survey of medicinal and edible plants of Yalo Woreda in Afar regional state Ethiopia," Journal of Ethnobiology and Ethnomedicine, vol. 13, no. 1, pp. 1-10, 2017.

[52] Z. Birhanu, "Traditional use of medicinal plants by the ethnic groups of Gondar Zuria district, North-Western Ethiopia," Journal of Natural Remedies, vol. 13, no. 1, pp. 46-53, 2013.

[53] M. Ragunathan and M. Solomon, "The study of spiritual remedies in Orthodox rural churches and traditional medicinal practice in Gondar Zuria district, Northwestern Ethiopia," Pharmacognosy Journal, vol. 1, pp. 178-183, 2009.

[54] M. Ragunathan and S. Abay, "Ethnomedicinal survey of folk drugs used in Bahirdar Zuria district, North West Ethiopia," Indian Journal of Traditional, vol. 8, pp. 281-284, 2009.

[55] G. Sharma, N. Tyagi, and B. Shrivastava, "Antioxidant and anticancer activity of Lagenaria siceraria fruit extracts On Mcf-7 cancer cell lines," International Research Journal of Pharmacy, vol. 10, no. 5, pp. 187-195, 2019.

[56] K. Lim, "Lagenaria siceraria," in Edible medicinal and nonmedicinal plants, vol. 4, pp. 298-313, Springer, Dordrecht, 2012.

[57] Y. Limenih, S. Umer, and M. Wolde-Mariam, "Ethnobotanical study on traditional medicinal plants in Dega Damot Woreda, Amhara region, North Ethiopia," International Journal of Research in Pharmacy and Chemistry, vol. 5, no. 2, pp. 258-273, 2015.

[58] A. Enyew, Z. Asfaw, E. Kelbessa, and R. Nagappan, "Ethnobotanical study of traditional medicinal plants in and around Fiche District, Central Ethiopia," Current Research Journal of Biological Sciences, vol. 6, no. 4, pp. 154-167, 2014.
[59] T. Teklehaymanot, "Ethnobotanical study of knowledge and medicinal plants use by the people in Dek Island in Ethiopia," Journal of Ethnopharmacology, vol. 124, no. 1, pp. 69-78, 2009.

[60] M. Ragunathan and M. Solomon, "The study of spiritual remedies in orthodox rural churches and traditional medicinal practice in Gondar Zuria district Northwestern Ethiopia," Pharmacognosy Journal, vol. 1, pp. 178-183, 2015.

[61] G. Yirga, "Assessment of indigenous knowledge of medicinal plants medicinal plants in Central Zone of Tigray Northern Ethiopia," African Journal of Plant Science, vol. 4, no. 1, pp. 6-11, 2010.

[62] E. d'Avigdor, H. Wohlmuth, Z. Asfaw, and T. Awas, "The current status of knowledge of herbal medicine and medicinal plants in Fiche, Ethiopia," Journal of Ethnobiology and Ethnomedicine, vol. 10, no. 1, pp. 37-38, 2014.

[63] S. Shin, A. Dekebo, W. Dinku et al., "Identification of an anticancer compound contained in seeds of Maesa lanceolata, a medicinal plant in Ethiopia," Journal of the Korean Society for Applied Biological Chemistry, vol. 57, no. 4, pp. 519-522, 2014.

[64] S. Tesfaye, A. Belete, E. Engidawork, T. Gedif, and K. Asres, "Ethnobotanical study of medicinal plants used by traditional healers to treat cancer-like symptoms in eleven districts, Ethiopia," Evidence-Based Complementary and Alternative Medicine, vol. 2020, Article ID 7683450, pp. 1-23, 2020.

[65] A. T, D. E, A. R et al., "Phytochemical constituents, safety and efficacy study of Thymus schimperi and Thymus serrulatus," Journal of Clinical and Experimental Pharmacology, vol. 9, no. 5, pp. 1-7, 2019.

[66] T. Teklehaymanot and M. Giday, "Ethnobotanical study of medicinal plants used by people in Zegie Peninsula, Northwestern Ethiopia," Journal of Ethnobiology and Ethnomedicine, vol. 3, no. 1, pp. 1-11, 2007.

[67] S. Araya, B. Abera, and M. Giday, "Study of plants traditionally used in public and animal health management in Seharti Samre District, Southern Tigray, Ethiopia," Journal of Ethnobiology and Ethnomedicine, vol. 11, no. 1, pp. 1-25, 2015.

[68] A. Kefalew, Z. Asfaw, and E. Kelbessa, "Ethnobotany of medicinal plants in Ada'a District, East Shewa Zone of Oromia Regional State, Ethiopia," Journal of Ethnobiologyand Ethnomedicine, vol. 11, no. 1, pp. 1-28, 2015.

[69] B. Kidane, T. van Andel, L. J. G. van der Maesen, and Z. Asfaw, "Use and management of traditional medicinal plants by Maale and Ari ethnic communities in southern Ethiopia," Journal of Ethnobiology and Ethnomedicine, vol. 10, no. 1, pp. 1-15, 2014.

[70] R. Yadav, "MPs in folk medicine system of Ethiopia," Journal of Poisonous and Medicinal Plants Research, vol. 1, pp. 7-11, 2013.

[71] B. Deressa, N. Cihoric, E. V. Badra, A. Tsikkinis, and D. Rauch, "Breast cancer care in northern Ethiopia crosssectional analysis," BMC Cancer, vol. 19, no. 1, pp. 1-6, 2019.

[72] S. Memirie, M. Habtemariam, M. Asefa et al., "Estimates of cancer incidence in Ethiopia in 2015 Using PopulationBased registry data," Journal of Global Oncology, vol. 4, pp. 1-11, 2018.

[73] D. Kamalanathan and D. Natarajan, "Antiproliferative and antioxidant potential of leaf and leaf derived callus extracts of Aerva lanata (L.) against human breast cancer (MCF-7) 
cell lines," Natural Products Journal, vol. 4, pp. 271-279, 2015.

[74] N. Tuasha, D. Seifu, E. Gadisa, B. Petros, and S. Oredsson, "Cytotoxicity of selected Ethiopian medicinal plants used in traditional breast cancer treatment against breast-derived cell lines," Journal of Medicinal Plant Research, vol. 13, no. 9, pp. 188-198, 2019.

[75] S. Tesfaye, H. Braun, K. Asres et al., "Ethiopian Medicinal Plants traditionally used for the treatment of cancer; Part 3: selective cytotoxic activity of 22 Plants against human cancer Cell Lines," Molecules, vol. 26, no. 12, p. 3658, 2021.

[76] O. Deniz and E. Kivark, "Effects of folic acid on rat kidney exposed to $900 \mathrm{MHz}$ electromagnetic radiation," Journal of Microscopy and Ultrastructure, vol. 5, no. 4, pp. 198-205, 2017.

[77] F. Bray, J. Ferlay, I. Soerjomataram, R. L. Siegel, L. A. Torre, and A. Jema, "Global cancer statistics 2018: GLOBOCAN estimates of incidence and mortality worldwide for 36 cancers in 185 countries," A Cancer Journal for Clinicians, vol. 68, no. 6, pp. 394-424, 2018.

[78] A. E. Mengesha and B. Youan, "Anticancer activity and nutritional value of extracts of the seed of Glinus lotoides," Journal of Nutritional Science and Vitaminology, vol. 56, no. 5, pp. 311-318, 2010.

[79] A. Terfaa and H. Tessoa, "Anticancer activity studies of root extract of Aloe pirottae A. Berger endemic plant species of Ethiopia," International Journal of Pharmaceutics and Drug Analysis, vol. 7, no. 6, pp. 49-53, 2019.

[80] M. Mohammadi, A. Majd, T. Nejadsattari, and M. Hashemi, "Antioxidant and anticancer activities of Ocimum basilicum L. cv. Dark Opal (Lamiaceae). Antioxidant effect of purple basil," Pharmacognosy Communications, vol. 4, no. 4, pp. 48-58, 2014.

[81] M. I. Choudhary, S. Hussain, S. Yousuf, A. Dar, Mudassar, and Atta-ur-Rahman, "Chlorinated and diepoxy withanolides from Withania somnifera and their cytotoxic effects against human lung cancer cell line," Phytochemistry, vol. 71, no. 17-18, pp. 2205-2209, 2010.

[82] E. Nibret, F. Sporer, K. Asres, and M. Wink, "Antitrypanosomal and cytotoxic activities of pyrrolizidine alkaloidproducing plants of Ethiopia," Journal of Pharmacy and Pharmacology, vol. 61, no. 6, pp. 801-808, 2010.

[83] R. Romeilah, "Chemical compositions, antioxidant, anticancer activities and biological effects of Myrtus communis L. and Origanum vulgare essential oils," Asian Journal of Biochemistry and Analytical Biochemistry, vol. 11, no. 2, pp. 104-117, 2016.

[84] A. Lichota and K. Gwozdzinski, "Anticancer activity of natural compounds from plant and marine environment," International Journal of Molecular Sciences, vol. 19, no. 11, p. 3533, 2018.

[85] M. Greenwell and P. Rahman, "Medicinal Plants: their Use in Anticancer Treatment," International Journal of Pharmaceutical Sciences and Research, vol. 6, no. 10, pp. 4103-4112, 2015.

[86] WHO, Skin Cancers in Ethiopia, World life expectancy, 2017.

[87] S. Ijaz, N. Akhtar, M. Khan et al., "Plant derived anticancer agents: A green approach towards skin cancers," Biomedicine and Pharmacotherapy, vol. 103, pp. 1643-1651, 2018.

[88] R. Khuda-Bukhsh, S. Bhattacharyya, S. Paul, and N. Boujedaini, "Polymeric nanoparticle encapsulation of a naturally occurring plant scopoletin and its effects on human melanoma cell A375," Zhong Xi Yi Jie He Xue Bao, vol. 8, no. 9, pp. 853-862, 2010.

[89] C. Wang, Y. Chiang, S. Sung, Y. Hsu, J. Chang, and P.-L. Kuo, "Plumbagin induces cell cycle arrest and apoptosis through reactive oxygen species/c-Jun N-terminal kinase pathways in human melanoma A375.S2 cells," Cancer Letters, vol. 259, no. 1, pp. 82-98, 2008.

[90] M. Galvez, C. Martín-Cordero, M. Lopez-Lazaro, F. Cortes, and M. J. Ayuso, "Cytotoxic effect of_Plantago_spp. on cancer cell lines," Journal of Ethnopharmacology, vol. 88, no. 2-3, pp. 125-130, 2003.

[91] C. D. Selassie, S. Kapur, R. P. Verma, and M. Rosario, "Cellular apoptosis and cytotoxicity of phenolic compounds: a quantitative structure- activity relationship study," Journal of Medicinal Chemistry, vol. 48, no. 23, pp. 7234-7242, 2005.

[92] F. B. Okoye, A. Debbab, V. Wray, C. O. Esimone, P. O. Osadebe, and P. Proksch, "A phenyldilactone, bisnorsesquiterpene, and cytotoxic phenolics from Maytenus senegalensis_leaves," Tetrahedron Letters, vol. 55, no. 28, pp. 3756-3760, 2014.

[93] W. Ma, Y. Zhang, Y. Y. Ding, F. Liu, and N. Li, "Cytotoxic and antiinflammatory activities of phenanthrenes from the medullae of Juncus effusus L.," Archives of Pharmacal Research, vol. 39, no. 2, pp. 154-160, 2016.

[94] K. Ishiuchi, Y. Kosuge, H. Hamagami et al., "Chemical constituents isolated from Juncus effusus induce cytotoxicity in HT22 cells," Journal of Natural Medicines, vol. 69, no. 3, pp. 421-426, 2015.

[95] T. P. Xu, H. Shen, L. X. Liu, and Y. Q. Shu, "Plumbagin from Plumbago Zeylanica L induces apoptosis in human nonsmall cell lung cancer cell lines through NF- $\kappa$ B inactivation," Asian Pacific Journal of Cancer Prevention, vol. 14, no. 4, pp. 2325-2331, 2013.

[96] C. A. Chen, H. H. Chang, C. Y. Kao, T. Tsai, and Y. Chen, "Plumbagin, Isolated from_Plumbago zeylanica_, Induces Cell Death through Apoptosis in Human Pancreatic Cancer Cells," Pancreatology, vol. 9, no. 6, pp. 797-809, 2009.

[97] S. Habtemariam, "Knipholone anthrone from Kniphofia foliosa induces a rapid onset of necrotic cell death in cancer cells," Fitoterapia, vol. 81, no. 8, pp. 1013-1019, 2010.

[98] D. Tungmunnithum, A. Thongboonyou, A. Pholboon, and A. Yangsabai, "Flavonoids and other phenolic compounds from medicinal plants for pharmaceutical and medical aspects: An Overview," Medicines, vol. 5, no. 3, p. 93, 2018.

[99] L. Wen, D. Wu, Y. Jiang et al., "Identification of flavonoids in litchi (Litchi chinensis Sonn) leaf and evaluation of anticancer activities," Journal of Functional Foods, vol. 6, pp. 555-563, 2014.

[100] H. Chun, H. Chang, E. Choi, H. J. Kim, and K. H. Ku, "Molecular and absorption properties of 12 soy isoflavones and their structure-activity relationship with selected biological activities," Biotechnology Letters, vol. 27, no. 15, pp. 1105-1111, 2005.

[101] M. Chahar, N. Sharma, M. Dobhal, and Y. Joshi, "Flavonoids: A versatile source of anticancer drugs," Pharmacognosy Reviews, vol. 5, no. 9, pp. 1-12, 2011.

[102] P. Batra and A. Sharma, "Anti-cancer potential of flavonoids: recent trends and future perspectives," 3 Biotech, vol. 3, no. 6, pp. 439-459, 2013. 
[103] S. Ahmede, M. Hayat, M. Tahir et al., "Pharmacologically active flavonoids from the anticancer, antioxidant and antimicrobial extracts of Cassia angustifolia Vahl," BMC Complementary and Alternative Medicine, vol. 16, no. 1, pp. 1-9, 2016.

[104] J. Lu, J. JBao, X. Chen, M. Huang, and Y.-T. Wang, "Alkaloids isolated from natural herbs as the anticancer agents," Evidence-Based Complementary and Alternative Medicine, vol. 2012, Article ID 485042, 12 pages, 2012.

[105] K. Mohan and R. Jeyachandran, "Alkaloids as anticancer agents," Annals of Phytomedicine, vol. 1, no. 1, pp. 46-53, 2012.

[106] J. A. Salvador, J. F. Carvalho, M. A. Neves, S. M. Silvestre, A. J. Leitao, and M. M. C. Silva, "Anticancer steroids: linking natural and semi-synthetic compounds," Natural Product Reports, vol. 30, no. 2, pp. 324-374, 2013.

[107] F. Maiyoa, R. Moodley, and M. Singh, "Phytochemistry, cytotoxicity and apoptosis studies of $\beta$-sitosterol-3-oglucoside and $\beta$-amyrin from Prunus africana," African Journal of Traditional, Complementary and Alternative Medicines, vol. 13, no. 4, pp. 105-112, 2016.

[108] S. M. Kupchan, J. Moniot, C. Sigel, and R. J. Hemingway, "Tumor inhibitors. LXV. Bersenogenin, berscillogenin, and 3-epiberscillogenin, three new cytotoxic bufadienolides from Bersama abyssinica," Journal of Organic Chemistry, vol. 36, no. 18, pp. 2611-2616, 1971.

[109] S. M. Kupchan, R. J. Hemingway, and J. C. Hemingway, “The isolation and characterization of hellebrigenin 3-acetate and hellebrigenin 3,5-diacetate, bufadienolide tumor inhibitors from Bersama abyssinica," Tetrahedron Letters, vol. 9, no. 2, pp. 149-152, 1968.

[110] P. C. Kuo and T. H. Kuo, "Physanolide A, a Novel skeleton steroid, and other cytotoxic principles from Physalis angulata," Organic Letters, vol. 8, no. 14, pp. 2953-2956, 2006.

[111] B. Bayala, I. Bassole, R. Scifo et al., "Anticancer activity of essential oils and their chemical components - a review," American Journal of Cancer Research, vol. 4, no. 6, pp. 591607, 2014.

[112] H. Shaaban, A. H. el-Ghorab, and T. Shibamoto, "Bioactivity of essential oils and their volatile aroma components: Review," Journal of Essential Oil Research, vol. 24, no. 2, pp. 203-212, 2012.

[113] A. War and M. Paulraj, "Mechanisms of plant defense against insect herbivores," Plant Signaling \& Behavior, vol. 7, no. 10, pp. 1306-1320, 2012.

[114] Y. Mukhtar, M. Adu-Frimpong, and X. Xu, "Biochemical significance of limonene and its metabolites: future prospects for designing and developing highly potent anticancer drugs," Bioscience Reports, vol. 38, no. 6, 2018.

[115] L. S. Mesquita, T. R. Luz, J. W. Mesquita et al., "Exploring the anticancer properties of essential oils from family Lamiaceae," Food Reviews International, vol. 35, no. 2, pp. 105$131,2019$.

[116] M. Qaid, N. Al-Hajj, M. Algabr, H. Raza, R. Thabi, and W. Al-Farga Ammar, "Anticancer, antimicrobial and antioxidant activities of the essential oils of some aromatic medicinal plants (Pulicaria inuloides-Asteraceae)," Journal of Food and Nutrition Research, vol. 5, no. 7, pp. 490-495, 2017.

[117] Y. Bhalla, V. Gupta, and V. Jaitak, "Anticancer activity of essential oils: a review," Journal of the Science of Food and Agriculture, vol. 99, pp. 3643-3653, 2013.
[118] S. Subramaniam, K. Selvaduray, and A. Radhakrishnan, "Bioactive compounds: natural defense against cancer," Biomolecules, vol. 9, no. 12, p. 758, 2019.

[119] P. Garg and A. Deep, "Anti-cancer potential of boswellic acid. A Mini Review," Journal for Drugs And Medicines, vol. 7, no. 2, pp. 18-27, 2015. 